\title{
USING RECENT ADVANCES IN 2D SEISMIC TECHNOLOGY AND SURFACE GEOCHEMISTRY TO ECONOMICALLY REDEVELOP A SHALLOW SHELF CARBONATE RESERVOIR: VERNON FIELD, ISABELLA COUNTY, MI.
}

TYPE OF REPORT: QUARTERLY

REPORTING PERIOD START DATE: SEPTEMBER 1, 2002

REPORTING PERIOD END DATE: DECEMBER 31, 2002

PRINCIPAL AUTHORS:

JAMES R. WOOD, - MICHIGAN TECHNOLOGICAL UNIVERSITY, HOUGHTON, MI W. QUINLAN, CRONUS EXPLORATION COMPANY LLC, TRAVERSE CITY, MI.

DATE REPORT WAS ISSUED: JANUARY, 2003

DOE AWARD NUMBER: DE-FC26-00BC15122

NAME AND ADDRESS OF SUBMITTING ORGANIZATION:

MICHIGAN TECHNOLOGICAL UNIVERSITY

1400 TOWNSEND DRIVE

HOUGHTON, MI. 49931 


\section{DISCLAIMER}

This report was prepared as an account of work sponsored by an agency of the United States Government. Neither the United States Government nor any agency thereof, nor any of their employees, makes any warranty, express or implied, or assumes any legal liability or responsibility for the accuracy, completeness, or usefulness of any information, apparatus, product or process disclosed, or represents that its use would not infringe on any privately owned rights. Reference herein to any specific commercial product, process, or service by trade name, trademark, manufacturer, or otherwise, does not necessarily constitute or imply its endorsement, recommendation or favoring by the United States Government nor any agency thereof. The views and opinions of authors expressed herein do not necessarily state or reflect those of the United States Government. 


\begin{abstract}
Presented in this quarterly report is the Case History and Well Summary for the Vernon Field demonstration project in Isabella County, Michigan. This new case history and well summary format organizes and presents the technical and historical details of the Vernon Field demonstation, as well as the field demonstration results and the applicability of these results to other demonstration projects. This format could be duplicated for other demonstration projects and will be used on all subsequent field demonstrations as they near completion.

Planning for the annual project meeting in Tampa, Florida has begun. This meeting will be held March 7-9, 2003 at the same site as the last three meetings.
\end{abstract}


TABLE OF CONTENTS

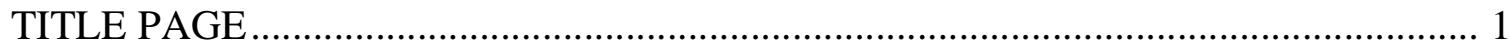

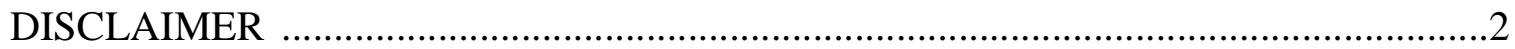

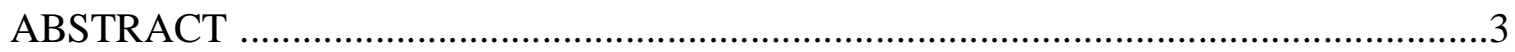

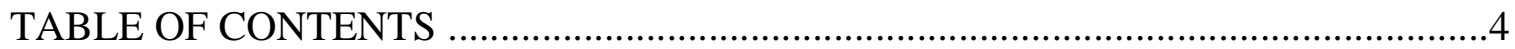

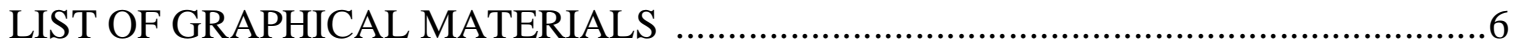

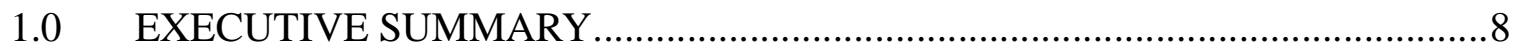

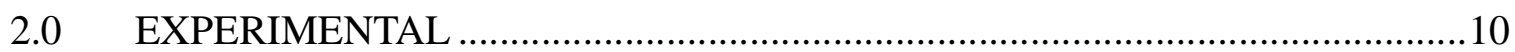

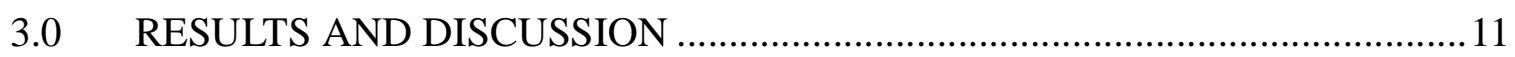

$3.1 \quad$ VERNON FIELD HISTORY ............................................................................... 11

3.2 RESERVOIR PROPERTIES.................................................................................... 11

3.3 PRODUCTION ENGINEERING -how wells completed and produced........................... 12

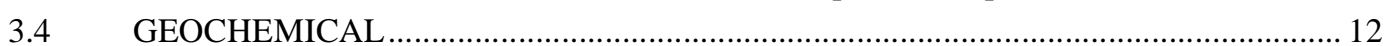

3.4.1 Sampling Program ....................................................................................... 13

3.4.2 Sample collection........................................................................................ 13

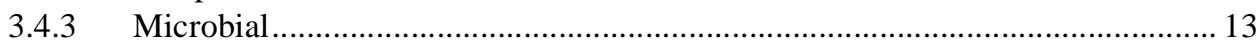

3.4.4 Sorbed Soil gas ........................................................................................ 15

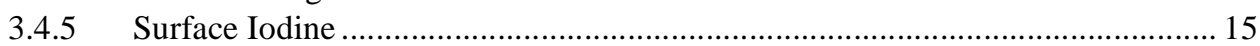

3.4.6 Trace Element and Rare Earths - Enzyme Leach Selective Extraction ................ 16

3.4.7 Site Specific Micro Extraction (SPME) fiber ....…………………………………16 16

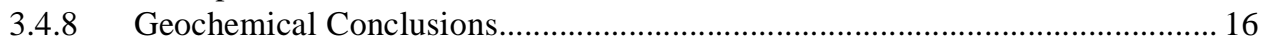

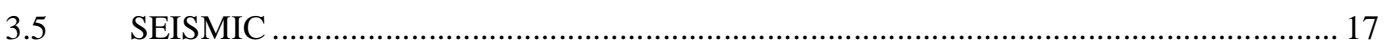

3.6 WELL DETAILS - STATE VERNON \& SMOCK 13-23 \#HD1 AND \#HD1A ................ 17

3.6.1 Overview........................................................................................ 17

3.6.2 Prospect Background …………………………………………………………... 17

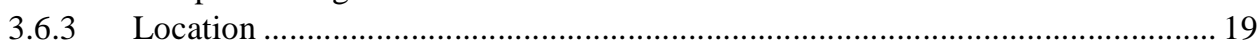

3.6.4 Drilling and Casing history ................................................................................ 19

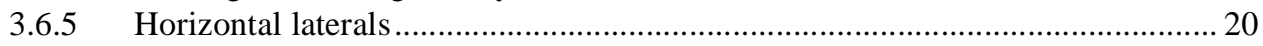

3.6.6 Open hole testing, coring, mudlogging, and logging ........................................ 20

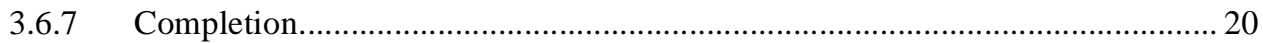

3.6.8 Comparison of Actual Results vs. Predicted ................................................... 21

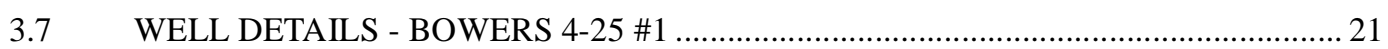

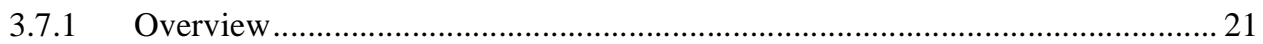

3.7.2 Prospect Background ………………………………………………………….... 21

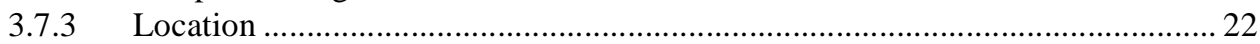

3.7.4 Drilling and Casing history ………………………………………………...22

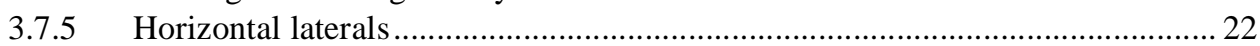

3.7.6 Open hole testing, coring, mudlogging, and logging ..................................... 22

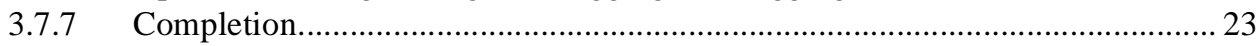

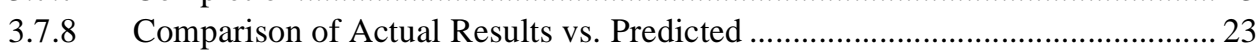

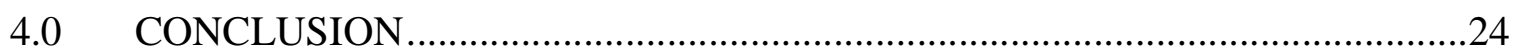

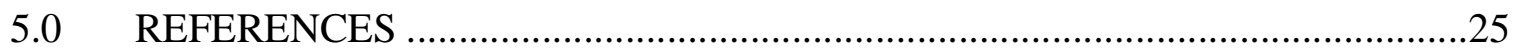

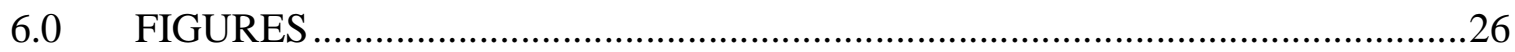

7.0 APPENDIX 1 - AAPG papers presented on Vernon Demonstration ......................47

7.1 AAPG Eastern Meeting, Kalamazoo, MI 2001

Results of Surface Geochemistry Survey over theVernon Field, Isabella County, MI .... 47 
7.2 AAPG Eastern Meeting, Kalamazoo, MI 2001

Results of Recent Drilling at Vernon Field, Isabella County, MI. and A Geologic Model for the Top of the Dundee Fm. 48

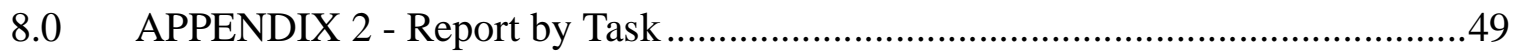

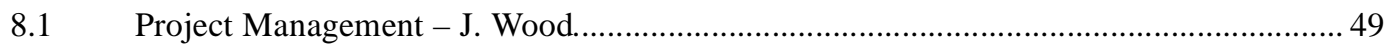

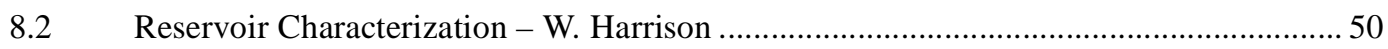

8.3 Analysis of Producibility Problem(s) - W. Quinlan..................................................... 51

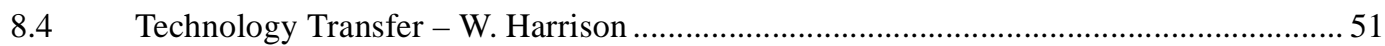




\section{LIST OF GRAPHICAL MATERIALS}

Figure 1. Six county index map for central Michigan showing the location of Vernon Field and other Dundee Fields. Vernon Field is located in north central Isabella County. Noth is toward the top of the page. Inset map shows location in lower peninsula of Michigan.

Figure 2. Index map showing Vernon-Rosebush Field area and isopach map from top of Traverse to top of Dundee Formation (interval overlying the productive interval); contour interval $10 \mathrm{ft}$. Green well symbols are oil wells producing from the Dundee/Rogers City or Dundee/Richfield and red well symbols are gas wells producing from the shallower Stray sand. Rectangle indicates Vernon Field.

Figure 3. Generalized stratigraphic column for Michigan Basin.

Figure 4. Structure map overVernon Field showing approximately $30 \mathrm{ft}$ of structural closure; contour interval $10 \mathrm{ft}$. Black dashed line shows location of Mission Road geochemical profile. Green well symbols are producing wells or abandoned producers. Rectangles are one square mile sections. North is to the left.

Figure 5. Annual oil and water production for the Vernon Field 1930 through 1983.

Figure 6. Annual drilling history for theVernon Field 1930 through 1983.

Figure 7. Approximate location of two laterals from State Vernon and Smock well. Solid black circles are oil wells and open circles are microbial sample points. The size of the open circles is proportional to the geochemical signal.

Figure 8. Mission Road Microbial data profile showing ray, smoothed and three-point averages of microbial data. North is toward the top of the page.

Figure 9. Structure contour map showing location of geochemical anomalies along the Mission Road profile. The location of the StateVernon and Smock well is also shown. Contour interval is $10 \mathrm{ft}$ and north is to the left.

Figure 10. Vernon Field area map showing microbial geochemical profiles. Bubbles are proportional to size of anomalies. North is to the right.

Figure 11. Vernon Field area map showing contoured microbial geochemical profiles. Bubbles are proportional to size of anomalies. Contour interval is two units. North is to the right.

Figure 12. Iodine and microbial data for Mission Road profile.

Figure 13. Enzyme leach trace element Mission Road profiles for $\mathrm{Mn}$ andV, $\mathrm{Zn}$ and $\mathrm{Cu}, \mathrm{Ba}$ and $\mathrm{Sb}$, As and $\mathrm{Se}, \mathrm{Ni}$ and $\mathrm{Co}$, and $\mathrm{Br}$ and $\mathrm{Sr}$.

Figure 14. Enzyme leach trace element Mission Road profiles for Rb and Zr, Mo andY, Ce and $\mathrm{La}$, Th and $\mathrm{U}$, and $\mathrm{Sm}$ and $\mathrm{Nd}$. 
Figure 15. State Vernon \& Smock 13-23 \#HD1 and \#HD1A well path, curve, and horizontal laterals. Log curves are gamma ray on left or bottom and neutron curve on right or top in log track. Mudlog images shown along path. Inset map shows location of well and laterals in Section 23, in the southwest quarter and structure on the top of the Dundee.

Figure 16. Dundee cap rock isopach map showing pre-drill geology for the Vernon Field and the location of the State Smock well. North is to the left. Prepared by Eric Taylor.

Figure 17. State Vernon and Smock post drill well bore schematic. See Figure 16 for location of cross section (interpretation by Eric Taylor).

Figure 18. State Vernon and Smock post drill well bore schematic showing interpreted path of laterals (interpretation by Eric Taylor).

Figure 19. Structure map on top of Dundee porosity showing location of Bowers 4-25 well. The State Vernon and Smock well bore and lateral paths are also shown. (interpretation by Eric Taylor).

Figure 20. Bowers 4-25 well log. Gamma ray shown on left and neutron curve on right. 


\subsection{EXECUTIVE SUMMARY}

\section{Goals and Results}

The goals of this project were to: (1) test the use of multi-lateral wells to recover bypassed hydrocarbons and (2) to access the potential of using surface geochemistry to reduce drilling risk. Two new demonstration wells, the State-Smock and the Bowers 4-25, were drilled to test the Dundee Formation at Vernon Field for bypassed oil. Neither well was commercial, although both produced hydrocarbon shows.

An extensive geochemical survey in the vicinity of Vernon Field, covering much of Isabella County, has produced a base map for interpretation of anomalies in Michigan. Several potential new anomalies were discovered that could be further investigated.

\section{New Findings}

Our knowledge of the state of the upper Dundee Formation greatly increased as a result of the drilling of the State Smock. We now feel that the top of the Dundee nearthe Vernon Field represents an exposed karst surface spotted with deep sinkholes filled with shale, perhaps similar to modern day topography around Tampa, Florida.

\section{Lessons Learned}

The State Smock well has provided us with several lessons, the most important being that in drilling old fields like Vernon, it is best to begin with a drilling program that includes a vertical test well to verify the presence of a pay zone, then follow with a horizontal well with multi-laterals. In the case of the first demonstration well, the State Smock, no vertical well was drilled and the first lateral drilled encountered a shale plug that was avoided with the second lateral. A vertical well would probably have established the absence of a pay zone and avoided the cost of a lateral.. In the second demonstration well, the Bowers 4-25, a vertical well was drilled and when it failed to show a pay zone the well was abandoned. In both cases, the surface geochemistry indicated marginal plays.

It has also been learned that natural fractures may play a key role in the production of these carbonate reservoirs. Isolating productive regions from water conductive fractures may be an important issue in recovering significant bypassed reserves. In addition, formation damage due to pulverized cuttings and drill pipe abrasion appears to be a prevalent issue within porous zones, even after relatively short periods of lateral drilling exposure.

An additional lesson is that geochemical surveys, particularly microbial, are worthwhile in these fields. Microbial surveys are relatively inexpensive and in this case appeared to provide reliable guides to the presence or absence of hydrocarbons.

Finally, the value of spreading the funding over many demonstration wells (5-6 ?) rather than just 1-2 seems justified since that permits better testing of the geochemical predictions. 


\section{Applications}

The results of the Vernon demonstration wells can be applied to other shallow shelf carbonate reservoirs worldwide. In particular the application of appropriate surface geochemistry surveys seems warranted based on the work done here, as well as the advice to precede drilling the horizontal wells with vertical test wells to establish the presence of a pay zone.

The shallow-shelf carbonates in the Permian Basin, the mid-continent, and Rocky Mountains (e.g. Williston basin) are logical targets for application of these techniques.

\section{Did Data Support Project or Not?}

The surface geochemistry data did support the project quite well: it predicted that both of the demonstration wells would likely be marginal. In other words, the geochem did not show the strong anomalies that would justify drilling on the basis of that data alone.

The demonstration wells again showed the value of the vertical probe well in these situations.

\section{Future Work}

More geochemical work will be done in conjunction with further field demonstrations as part of this project. Several more techniques will be used, including SPME (Site Specific MicroExtraction) and analysis of carbon fibers.

New demonstration wells are planned for North. Dakota to test the Duperow Formation, as well as several in Michigan to test the pinnacle reef plays. Preliminary results using the microbial techniques show good anomaly patterns for the reefs.

\section{Should Something Else Have Been Done?}

The first test well, the State-Smock, should have had a vertical test well and perhaps more faith should have been placed in the geochemical results. However, if the State Smock and the Bowers 4-25 wells had not been drilled, the predictions of the geochemistry would not have been verified. 


\subsection{EXPERIMENTAL}

\section{DOE Field Demonstration Case History and Well Summary: VERNON FIELD, Isabella County, Michigan}

As part of the Class Revisit Program, a university-industry-DOE consortium drilled a multi-lateral well and a vertical well in Vernon Field, Isabella County, Michigan Prior to drilling, a surface geochemical survey was run over the area using several different geochemical techniques and a good anomaly was detected using microbial indicators. The surveys were conducted in several stages in May and August of 2000 and later in November as the well was being drilled. The May survey was a north-south line profile across Vernon Field parallel to Mission Road and was designed to test several geochemical methods. These included: surface iodine, enzyme leach on samples from the "B" soil horizon, head space gases from sample depths of about 36 inches, and microbial. The results indicated that the microbial survey produced the best results and this geochemical method was adopted for all subsequent surveys. The May survey detected a positive microbial anomaly over the site of the proposed State Vernon \& Smock \#13-23 well, which was confirmed by both subsequent surveys. 


\subsection{RESULTS AND DISCUSSION}

\section{DOE Field Demonstration Case History and Well Summary: VERNON FIELD, Isabella County, Michigan}

\subsection{VERNON FIELD HISTORY}

Vernon Field is located in T16N-R4W in Vernon Township, Isabella County MI (Figure 1 and 2). The field was developed in the 1930's. Most wells were drilled by 1935. The field was redeveloped once in the 1950s and several new wells were drilled in the 1980s. The field development predated all other Dundee discoveries in the state except for Port Huron, Muskegon, and Mt. Pleasant. The main producing zone is the upper Dundee ("Rogers City"), which is a shallow-shelf carbonate (Figure 3), locally altered to porous, vugular dolomite by hydrothermal fluids. The field was generally developed on 10-acre spacing (Figure 4) with several secondary disposal wells. Most wells had high initial production rates of up to 5000 barrels of oil per day, however, the production rates dropped off rapidly and many wells were abandoned by the late 1940s (Figure 5 and 6). The field produced 5 million barrels of oil from the original 78 wells with an average recovery of 5,700 barrels (bbls)/acre. The field is situated on a plunging anticline, but the oil pool is primarily the result of an updip permeability barrier-type stratigraphic trap, sealed to the south by impervious limestone. The top seal is the Bell Shale. Reservoir pressure is maintained by a strong bottom-water drive and the original oil-water contact is projected at a subsea depth of -2950 feet. The maximum gross pay thickness is 55 feet.

\subsection{RESERVOIR PROPERTIES}

Dundee reservoirs are generally composed of two lithologic types - limestone and dolomite. The limestone depositional facies reflect original depositional lithologies including grainstone shoal carbonate sand, fenestral peritidal packstones and wackestones, and stromatoporoid/coral boundstone patch reefs. The dolomite facies are related to the overprinting of burial diagenetic fabrics onto the limestones including hydrothermal dolomites resulting in fractured and vuggy fabrics and sucrosic to laminated dolomite with nodular to bedded anhydrite fabrics. Dolomite reservoirs have pervasive replacement of the original limestone fabric. However, in some cases the original depositional fabric is preserved and provides a template for additional diagenesis. Solution enhanced pores, vugs, and fractures are common and often contain saddle or hydrothermal dolomite cements (HDT). In some Dundee Fields the drillers report bit drops of two to three feet (Fitzgerald and Thomas, 1932) suggesting open fractures may be common. In the Vernon Field, fluorite has also been found in the solution cavities in the reservoir rock as well developed crystals (Fitzgerald and Thomas, 1932) suggesting that Mississippi-valley-type (MVT) hydrothermal processes may have played a role in the creation of the reservoirs. Stylolites are abundant in the Dundee as the result of chemical compaction during burial diagenesis.

Fractures enhance the permeability, especially the vertical permeability, in many Dundee reservoirs. The original limestone porosity fabric has also been altered and modified by the movement of fluids along these fractures. Fractures have enhanced permeability and porosity and thus oil productivity but they have also allowed the coning of water during production of these reservoirs. 
In the Vernon Field, the reservoir occurs in the upper portion of the Dundee Formation in the Rogers City Member. The reservoir is comprised predominately of vuggy dolomite lenses or beds interbedded with tight dolomite. Net porous interval to total interval ratio (net to gross ratio) is estimated at 60 percent. Fractures help connect vuggy and matrix pores.

Openhole electric logs and porosity logs are not common in most Dundee fields developed before 1970. However, drillers logs and sample reports are available for many of the wells and can be useful for interpretation. Initial potential data from the wells can be used to characterize the general reservoir architecture and pore network.

\subsection{PRODUCTION ENGINEERING -how wells completed and produced}

Engineering parameters are generally not directly available for the old wells in this field. It may be possible to estimate some parameters from production history data and the few wireline logs in the field. Production history data has been compiled courtesy of Eric Taylor, Consulting Geologist from Traverse City, Michigan (Figure 5). Very high initial rates were recorded from the field, but production dropped rapidly.

An observation by Bill Harrison (personal communication) indicates that the water production history in Dundee dolomite reservoirs is different than the water production from limestone reservoirs. In addition, historical reservoir management practices by the operators have had dramatic effects on the recovery of oil, gas, and water. Limestone fields are mainly solution gas or pressure depletion drive reservoirs and are good candidates for enhanced recovery. Dolomite reservoirs are primarily water drive and may have high primary recovery and limited enhanced recovery potential.

\subsection{GEOCHEMICAL}

A surface geochemistry program was initiated atVernon Field in order to discover if geochemical anomalies were associated with the field. The surveys were designed to examine four different geochemical techniques based on a literature review and discussions with vendors. The four geochemical techniques to be evaluated were: surface iodine, microbial, enzyme leach, and soilgas. These are established techniques with a supportive literature and a number of service companies willing to conduct the surveys and/or do the analyses. In this study, project personnel collected all samples and interpreted the data. Commercial service companies conducted the analyses.

Although we started with no bias toward or against any one technique, we moved to an initial position favoring the microbial data because it gave a positive (apical) anomaly that is easy to interpret. Another technique that might be as good or even better, direct measurement of soil gas hydrocarbons, was not pursued as vigorously due to the cost of analysis ( $\$ 50-200 /$ sample) and the difficulty of sample collection (samples are taken from 3-4 foot depths). However, this technique might have warned us that the demonstration well was located over a poor site. We are not yet committed to any one technique and will continue to examine other geochemical techniques in subsequent demonstration well areas. 


\subsubsection{Sampling Program}

A geochemical sampling program for the Vernon Field, Isabella Co., Michigan was initiated during the spring of 2000. An area ofVernon Field approximately 2-3 square miles in area was sampled over a period of six months from May 2000 to November 2000. Four separate sampling trips were taken and over 360 sample sites visited. Multiple samples were collected at several sites.

On May 12, 2000, the first or reconnaissance phase of geochemical sampling over the field was completed. The Mission Road profile (Orientation Profile) was completed and a total of 50 locations spaced 300 feet apart were sampled (Figure 3). The Mission Road profile is a N-S profile adjacent to Mission Road across the field. Four types of samples were collected: surface microbial, enzyme leach, iodine, and soil gas. In addition, 3 samples were collected over the proposed horizontal drill hole, the State Smock.

The initial line survey was extended to include 148 more samples arrayed across five 5 1-2 mile lines (Figure 7). Samples were collected for 3 types of analysis, microbial, iodine, and enzyme leach (sorbed soil gas was dropped.) To date, eight sampling trips have been made to Vernon Field and vicinity and over 800 samples have been collected for geochemical analyses.

\subsubsection{Sample collection}

Soil samples were collected for microbial analysis, surface iodine, enzyme leach selective extraction, and soil head gas at selected localities. Duplicate samples were analyzed to evaluate precision error. Sample site locations were recorded in the field with a hand held GPS and plotted on base maps derived from the Michigan DNR spatial data library.

On the first sampling trip, samples were collected along a line profile (1D survey) at 200 meter (600 feet) spacing (Figure 4). It was necessary to establish a grid spacing that would adequately sample the anomaly without over sampling. One requirement we attempted to meet was to sample one square mile per day. As mentioned, the MRP was sampled at nominally 200 meters (600 feet). Although this spacing appeared adequate, it was decided tighter spacing was needed over the fields and a spacing of 100 meters was adopted for the grid in both directions. This spacing works out to 8 samples per mile or 64 samples per square mile. This spacing was found to produce good contour maps of the microbial anomalies but may not be sufficiently dense to resolve all features. Assuming 20 minutes to walk 1 mile, then 8 samples per mile leaves 5 minutes per station if we want to cover 1 mile in an hour. Microbial samples can be collected in this time, including reading and recording the site location. We found that one man could easily make four 1-mile traverses per day e.g. cover $1 / 2$ square mile. The optimal sampling team was found to be a team of two men sampling 1 square mile per day, each collecting 32 samples.

\subsubsection{Microbial}

The microbial oil survey technique is based on the principal that hydrocarbon gases in the soil directly influence the microbial population over an oil reservoir. These gases escape from the hydrocarbon reservoir and migrate upwards in very small quantities (microseeps). Specific organisms are associated with hydrocarbon gases and there is an expected positive correlation 
with amount of microbes and occurrence of hydrocarbons at depth. The microbial technique is based on the premise that microbes living in the soil are unique depending on their food (energy) source. Microbes that thrive on light hydrocarbon gases $(\mathrm{C} 1-\mathrm{C} 4)$ in particular are known to feed exclusively on these gases, even to the extent that one microbe may consume only one type of gas composition (e.g., C3). The technique is based on culturing these microbes in a laboratory for a period of time on a special substrate and then counting the microbe population. Samples are collected 8 inches below ground surface and cultured within 48 hours of collection. The main assumption is that the microbes will be present if the gases are present and that the microbes will be absent otherwise. Since C2 - C4 hydrocarbons are widely thought to originate only from gas and oil accumulations, the presence of microbes specialized to feed on these gases is taken as evidence of a migration of hydrocarbons from the reservoir to the surface. An anomaly should remain only as long as hydrocarbons of sufficient quantity exist in the subsurface to provide microseepage of gases to the surface. Thus, this technique can be used to detect by-passed oil in depleted reservoirs.

Geo-Microbial Technologies Inc. in Ochelata, OK did the analyses (www.gmtgeochem.com).

The raw results for microbial are given in Table 1. Microbial data are log-normally distributed based on visual inspection and the KS statistical test. The median value is 12 . The $90 \%$ quintile is a value of 30 and values above 30 are considered anomalous. A total of 6 out of 50 analyses are greater than 30 with 3 of these samples taken directly above the proposed horizontal well. Microbial data show an apical anomaly over the center of the Vernon field. Microbial is variable and generally below 25 off of the center of the field. These results suggest by-passed oil potential is good in the area of the proposed horizontal well.

The microbial Mission Road profile results are shown in Figures 8 and 9. Samples were collected at 200 meter (600 feet) spacing. It is apparent that the high values occur over the known extents of Vernon Field, and the samples collected over the proposed drill site initially appeared to show anomalies. Results for the 2D microbial survey over the Vernon Field study area are shown in Figure 10 and 11. The sampling locations are indicated and the bubbles in Figure 10 represent values of microbial density as cultured in the laboratory from the field samples. In general, the data show lows to the west over the part of Vernon Field that is still under production, increasing to the East with a still unresolved high outside the filed to the Northeast. This high nominally lies along Isabella Road and has been termed the Isabella High. The origins of this high are unknown, but may be due to gas in the shallow Pennsylvanian Stray Formation. Geologic data suggests that it is unlikely to be due to a Dundee source but this has not been definitively ruled out. There is a microbial high over the demonstration well, but statistical analysis suggests that this should be regarded as a marginal anomaly. Data collected over the site of the second well, the Bowers \#4-25 in the East Vernon Prospect (Figures 9 and 10) show a similar anomaly.

Trost [1993, A Limited Data set Comparison of Headspace Soil Gas and the "MOST" Biogeochemical Technique to Evaluate Drill Site Potential, Bulletin of Association Petroleum Geochemical Explorationists, 9(1), Gary Price (ED), p. 63-80] suggests that the values provided by GMS from their microbial data can be generally classified as: 
TABLE 1.

\begin{tabular}{|c|c|c|c|}
\hline $\begin{array}{l}\text { MICROBIAL } \\
\text { VALUE }\end{array}$ & RANKING & N SAMPLES & PERCENT \\
\hline $0-30$ & POOR & 402 & 36 \\
\hline $30-60$ & MARGINAL & 455 & 42 \\
\hline $60-90$ & GOOD & 199 & 18 \\
\hline$>90$ & EXCELLENT & 46 & 4 \\
\hline
\end{tabular}

The data we have acquired using microbial technology (MOST) are shown in the two right hand columns above. The sample locations are plotted in Figure 10. Of the nearly 1100 geochemical samples collected (about 300 from outside the Vernon Field), roughly 22\% (245) rank as "Good" or better. (microbial values for all 1100 samples ranged from 1 to 157.) Using these criteria, our first demonstration well, the State Vernon \& Smock \#13-23, had microbial values that lay in the ranges "Marginal" to "Good", while the second demonstration well, the Bowers 4-25, has microbial values that are mainly marginal. The rational for drilling these projects was to "ground truth" the geochemical data, regardless of whether the geochemistry was good or poor.

\subsubsection{Sorbed Soil gas}

The sorbed soil gas method (Horvitz, 1985) involves acid extraction of light hydrocarbon gases that are sorbed onto clays or incorporated into carbonate cements in near-surface soils. The gases accumulate through microseepage from the hydrocarbon reservoir. Geo-Microbial Technologies, Inc. (GMT) determined the sorbed soil gases by flame ionization detector gas chromatography of the scrubbed and liberated gases. Soil samples were collected from approximately one-meter depth, placed into a metal collection can along with biocide (supplied by GMT). The concentration of light hydrocarbons can be used as an indicator of increased hydrocarbon microseepage. The ratios of the hydrocarbons, combined with published empirical soil gas ratios (Jones and Drozd, 1983) can be used to establish whether a prospect is in an oil, gas, or mixed prone region.

GMT website http://216.29.207.22/gmtgeochemcom/\#

\subsubsection{Surface Iodine}

Iodine in surface soil samples has been demonstrated in the literature as an effective pathfinder for oil and gas in the subsurface (Gallagher, 1995). High concentrations of iodine are documented elsewhere around the perimeter of subsurface oil and gas accumulations, "classic" halo anomaly, and directly above the accumulation, apical anomaly. The halo effect is interpreted as the surface expression of a reduction pipe above the oil and gas accumulation. Soil was collected from the top one inch of the A-horizon for surface iodine analysis. Data and interpretations for this survey are shown in Figure 12 and discussed in the geochemical conclusions. 
Graystone Exploration Labs Inc., Golden, Colorado conducted the analyses. (http://www.geotech.org/survey/ssiweb/ssiweb.html)

\subsubsection{Trace Element and Rare Earths - Enzyme Leach Selective Extraction}

The enzyme leach selective extraction method is based on selective extraction of elements trapped on amorphous $\mathrm{MnO}_{2}$ (Clark). Amorphous $\mathrm{MnO}_{2}$ is a very effective trap for migrating cations, anions, and polar molecules. Oxidation anomalies are predicted over reduced bodies in the subsurface for a suite of elements including $\mathrm{Cl}, \mathrm{Br}$, I, As, Sb, Mo, W, Re, Se, Te, V, U, and Th (oxidation suite). Rare-earth elements often follow the same pattern as the oxidation suite. Base metals can be anomalous, but with lower contrast with the background. According to Clark, the most common form of oxidation anomalies is as a halo with a central low over the reduced body in the subsurface. These anomalies may be symmetric, asymmetric, or partial around the buried reduced bodies. Clark provides an electrochemical interpretation for halo oxidation anomalies. Apical anomalies are most often interpreted as related to faults. Since enzyme leach anomalies take 100's of years to develop, they will exist long after oil has been extracted from a reservoir.

Soil was collected from just below the top of the B-horizon for enzyme leach selective extraction analysis. Analyses were done by Actlabs-Skyline, Tuscon, AZ (www.actlabs.com). The plotted results are shown in Figures 13 and 14.

\subsubsection{Site Specific Micro Extraction (SPME) fiber}

A new sampling technique not used at Vernon but planned for other demonstration sites.

\subsubsection{Geochemical Conclusions}

There is hydrocarbon microseepage from the Dundee reservoir of theVernon Field that is detectable by surface soil geochemical techniques. Microbial data show a pronounced apical anomaly over the field and were elevated above the horizontal well. (The sorbed or headspace gas data strongly suggested that the location was poor.) The microbial data suggest good potential for bypassed oil especially over undrilled areas of the field. The microbial results have reasonable repeatability.

The surface iodine and oxidation suite enzyme leach results show a halo anomaly coinciding with the main part of theVernon field with low values above the subsurface accumulation of oil in the Dundee and higher values at the edges of the field. Iodine values generally show opposite trends from the microbial data. Iodine surface samples are slightly different from Iodine values from the op of the 'B' soil horizon.

Enzyme leach trace elements show a halo pattern. $\mathrm{Cu}, \mathrm{Ni}, \mathrm{Mn}$, and $\mathrm{Th}$ show good halos and $\mathrm{Sr}$, $\mathrm{Rb}, \mathrm{Zr}, \mathrm{Ce}$, and $\mathrm{Sm}$ show fair halos. Some trace elements are not useful for defining anomalies representing the field area.

The Smock demonstration well showed that hydrocarbons were present in the Dundee horizon, but the distribution was spotty. Geochemical and well results indicate that the geochemical data 
has to be properly calibrated for local conditions and that good sampling protocol and a tight sampling grid are essential.

\subsection{SEISMIC}

Preliminary cost analysis carried out in the pre-planning stages for the Vernon Field demonstration showed 3D seismic to be to expensive for this type of project (the cost is comparable to the entire drilling operation).

A goal of using advanced 2D seismic technology in this project was postponed to Phase II to allow more time to design the survey and integrate it with the surface geochemistry. Drilling schedules, dictated by expiring leases, did not permit us to implement both a seismic and surface geochemistry program is Phase I or Phase II. However in the Vernon Field, having subsurface control through 100+ wells pretty well defined the subsurface anyway. In addition, the thin reservoir interval and seismically 'fast' carbonates may not be resolvable given required shooting parameters including surface glacial til and surface infrastructure.

\subsection{WELL DETAILS - STATE VERNON \& SMOCK 13-23 \#HD1 AND \#HD1A}

\subsubsection{Overview}

The State Vernon \& Smock \#13-23 was spudded October 5, 2000 in the Vernon Field and drilled to a total depth of 4630 feet, bottoming in the (Middle Devonian) Dundee Formation. Unfortunately, despite the good reservoir rock and numerous oil shows, the interval could not be produced and was abandoned January 12, 2001. The reason for the failure to produce is tentatively assigned to the hypothesis that the interval was previously drained by earlier wells.

The rational for selecting the Vernon area was the presence of attic oil. The Jordon prospect is situated on the most prolific lease in the Vernon Field. The object of the well was to test the ability of horizontal drilling technology to locate and produce reserves indicated by a surface geochemical survey. It was anticipated that the flexibility offered by the horizontal technology would permit probing the subsurface for pockets of by-passed oil via lateral offshoots. This was thought to be necessary due to the known production difficulties arising from the highly irregular contact between the top of the Dundee Formation and the bottom of the overlying Bell Shale. It is widely believed in Michigan that this contact represents an ancient erosion surface developed on karst. Given that the pay zones are usually only 10-15 feet thick, it is necessary to probe close to the contact without entering the bottom water and avoiding the overlying shale. The difficulty is measurably increased by the tendency to encounter shale "plugs" at the contact, which may be mudfilled sinkholes several 100 feet deep and 50-100 feet in diameter.

\subsubsection{Prospect Background}

Developed in 1933, the Stough farm was a lay down 80 acres tract with 5 oil wells on it. Cumulative production for the lease is $1,000,000$ barrels oil or 200,000 barrels per well. This amounts to a 
recovery per acre of 12,500 barrels. These outstanding recovery numbers are to be expected as the lease is favorably positioned near the updip margin of the reservoir dolomite facies. The average gross pay thickness for the 5 wells was 40 feet with several of the individual producers having as much as 55 feet of pay. The recoveries also indicate the reservoir quality is superior in this area. The State Vernon and Smock \#13-23 HD1 also stood to benefit from oil reserves left behind by the original wells. Relatively recent infill drilling in Vernon indicates the reservoir holds bypassed oil as water coning and/or faulty drilling procedures damaged the old producers.

A successful re-entry/sidetrack of an old hole sparked interest in Vernon, which resulted in 16 holes being drilled in and around the field during a four-year period from 1981 to 1985. Central Michigan Exploration re-entered and sidetracked the Bigelow-Stephens \#1 (P.N. 1301) in March of 1981. The well is located in the $\mathrm{NW}^{1} 1 / 4 \mathrm{NW}^{1} / 4 \mathrm{SE}^{1} / 4$ of section 22 . Completed in 1933 , the original hole was drilled 57 feet below the top of the Dundee and into the water. The well was plugged 45 days after reaching total depth. Upon topping the Dundee with the sidetrack, the new hole took off flowing at a rate of 200 BOPD natural. The well maintained a flow rate of 100 BOPD with no water for the first year of operation. Since the end of 1982, mechanical problems have hindered production. Estimated cumulative total for the Bigelow-Stephens \#1 is 50,000 barrels of oil. Of the new 16 wells drilled during the early 1980's, 7 were located in the interior of the field. However, all 7 were disadvantaged by being located 165 feet or less from an old plugged producer. Ideally, the new holes would have been spotted at undeveloped sites on the 49 acre units. Despite this drawback, 6 of the 7 wells proved to be semi-commercial for local operators. Initial production averages were 25 BOPD with 100 BWPD. Per well cumulative totals are approximately 30,000 barrels of oil. Although the oil recoveries achieved by the infill wells are rather modest, the numbers are considered important because they demonstrate the Vernon reservoir contains oil reserves bypassed by the original development.

One of the Vernon infill wells was the Stough \#1A-23 (NW1/4 SW1/4 SE1/4, 23) drilled by Summit Petroleum in 1982. The up hole portion of this well bore will be utilized in the drilling operations for the proposed horizontal well. The Stough \#1A-23 is located 130 feet south of an old, plugged producer. Originally planned as a deeper Richfield test, the well encountered severe lost circulation zones in the middle Dundee and as a result drilling had to be halted at the base of the horizon. Open hole wireline logs and a mud log are available from this test. The neutron porosity log indicates the upper Dundee lithology is dolomite with estimated porosity ranging between $5 \%$ and $12 \%$. The resistivity logs exhibit 32 feet of gross pay section and can be used to calculate a maximum water saturation of $30 \%$. The logs also display a oil-water contact at a depth of -2937 subsea. The drill cuttings from the top of the Dundee are described as porous dolomite with $100 \%$ fluorescence and streaming cut. A good gas show was measured across the upper 25 feet of the Dundee by the gas detector.

The Stough \#1A-23 was completed for 18 BOPD and 100 BWPD. Cumulative oil production is approximately 30,000 barrels. Based on the optimistic log and sample data from the well, these production numbers are disappointing. However, the completion of the well may have been undermined by a poor cement job. The cavernous porosity in the middle Dundee made a quality cement job difficult. The bond log from the well indicates the top of cement is at 3670', only 40' above the Dundee pay zone. In conclusion, although the Stough \#A1-23 proved to be a marginal 
producer, the encouraging log and sample data suggests the reservoir contains significant bypassed oil in the prospect area.

A lateral hole was thought to be an excellent method to evaluate this prospect. One advantage a horizontal well bore offers is that it allows the well to be produced at a higher rate without significantly reducing the bottom hole flowing pressure. This minimizes the chance of water coning thereby delaying water production. Where a conventional well can be produced at $50 \mathrm{BOPD}$, a horizontal well can be produced at 100 BOPD. This reduces payout time and increases return on investment. The horizontal well path was orientated south and east from the Stough \#1A-23 surface hole. The objective of the horizontal well was to follow the upper reservoir dolomite updip until it pinched out. The lateral hole was projected to start out at a TVD of -2905 subsea. Anticipated length of the lateral section was 1000 feet.

\subsubsection{Location}

The State Vernon and Smock \#13-23 HD1 drilling unit was drilled in Phase I of this project. It is described as the SW1/4 SE1/4 of section 23 and the NW $1 / 4$ of the NE $1 / 4$ of section 26, Vernon Township, Isabella Co.

Jordon secured approval from the Michigan Department of Environmental Quality (MDEQ) on the 80 acre Smock drilling unit in April 2000. The unit has an old Dundee well existing upon it (used as a brine source well for Isabella County), therefore, a spacing exception had to be petitioned to allow the 2 wells (the existing John Stough 1 and the Smock 13-23 HD) to produce. Jordon was able to get the unit ratified without the need for a time exhaustive formal hearing, and received approval from the MDEQ on April 24, 2000. The drilling permit application was then applied for pertaining to this unit. The permit was issued on June 14, 2000 for the State Vernon \& Smock 13-23 HD1 (permit number: PN 53945).

Jordon conducted a Baseline Environmental Assessment (BEA) upon the proposed Smock 13-23 HD drilling unit, including the drill site and future production facility site. The purpose of the BEA was to delineate any existing environmental contamination upon the unit prior to conducting any operations. The BEA was then submitted to the MDEQ for adequacy determination, which upon ratification, releases Jordon (Cronus) and its partners from liability associated with the existing contamination. The MDEQ affirmed the BEA on April 3, 2000.

\subsubsection{Drilling and Casing history}

The demonstration well was sited to pass on an East-West line between a gap in the 10-acre pattern (Figure 15 and 16) based on subsurface geology and historical production from previous wells. The first lateral drilled as expected until the bit exited the curve and failed to penetrate either limestone or dolomite. Drilling continued for 751 feet until it was determined that the shale was too extensive and the bit was pulled back, repositioned to penetrate 9 feet deeper and to the northeast of the first lateral. The second lateral penetrated carbonates as expected, including approximately 110 feet of good dolomitic reservoir. 


\subsubsection{Horizontal laterals}

The first lateral reached the top of the Dundee Formation at -2902 feet on October 26. Seven-inch casing was set at $4229 \mathrm{MD}$ and the lateral continued another 980 feet to $4982 \mathrm{MD}$. The trajectory of this lateral is shown in Figure 15 and 16. The lateral encountered shale immediately upon entering the target zone and was deviated upward then down in an effort to escape the shale. However, the well was thought to have hit the porous dolomite hydrocarbon zone (PDHZ) in the last 50 feet (Figure 15, 17, and 18) between depths of -2915 to -2920 . The only hydrocarbon show was a gas show of 320 units measured at 4192 MD just at the Dundee-Bell Shale contact. This lateral was abandoned on November 3, 2000 .

Based on information obtained from the first lateral, a second lateral was drilled on November 4th. This well was kicked off from the casing point at 4229 feet MD and targeted for the top of the PDHZ encountered in the first lateral. Accordingly the well was deviated down (Figures 15 and 18) and to the northeast. At 8 feet below the first lateral, the well encountered the PDHZ at about 4400 feet MD and attempted to follow the contact another 230 feet to 4630 feet MD (Figures 17 and 18) where it again encountered shale. At this point drilling was stopped on November 6th and attempts were made to produce the interval based on good hydrocarbon shows from 4405 to 4630 feet MD.

\subsubsection{Open hole testing, coring, mudlogging, and logging}

No drill stem testing or coring was performed in this well.

A mudlog was recorded in both laterals and included data on sample lithology, hydrocarbon shows, and gas in the mud.

A gamma ray tool was included in the drill string while drilling the horizontal laterals (LWD logging while drilling) to aid in determining the well bore location relative to the Bell Shale or any shale plugs.

Michigan Wireline Services recorded a gamma ray neutron open hole log in the well from surface to a depth of $3157 \mathrm{ft}$, the start of the curve, on October 17, 2000. An open hole pump down gamma ray-neutron-casing collar log was recorded in the curve and second lateral by Baker Hughes on November 14, 2000.

\subsubsection{Completion}

Work was undertaken to isolate and produce the reservoir section of the second lateral. During initial testing, it became evident that natural fracturing within the reservoir was contributing water production while bypassing recoverable oil reserves. In addition, it was learned that extensive formation damage while drilling probably resulted in plugging of the pay section within the lateral. Plans to run 4.5" casing through the second lateral were contemplated to effectively isolate the pay sections and effectively treat and produce them but was never completed due to economics and the low likelihood of successfully isolating the interval. 


\subsubsection{Comparison of Actual Results vs. Predicted}

It is possible to construct a detailed geologic model that fits the observations from the pre-existing wells and the demonstration well. We presently think that a karst model best fits the data, but this is open to other interpretations. The best way to visualize the karst model is through cross-sections taken at approximately right angles. Figures 17 and 18 are two such cross-sections. Figure 17 is a North-South cross-section taken along the line of section indicated in Figure 16. Figure 18 is an East-West cross-section taken approximately along the well trajectory, that is approximately along the trace of the lateral offshoots of the demonstration well shown in Figure 15. Note that the vertical scale is approximately the same in both cross-sections but the horizontal scale is smaller in Figure 18 than in Figure 17 by a factor of roughly $2 \mathrm{X}$.

Together these figures suggest that the overall geologic model for the Upper Dundee at Vernon Field is one of karstic topography with mud filling sinkholes or small canyons in the secondary dolomite facies but not the original limestone facies. It may seem curious that the sinkholes are confined to the dolomite facies, but a logical scenario is that the fluids that dolomitized the limestone simply followed the preexisting joints and fractures that developed the karst surface. It is possible that this is a faulted topography with some with minor (10-20 feet?) offsets. In any event, this model fits the observations and is consistent with what we know about the Dundee Formation in general.

\subsection{WELL DETAILS - BOWERS 4-25 \#1}

\subsubsection{Overview}

As a follow-up to the State Smock well, the Bowers 4-25 vertical well (originally proposed as the White \#1-24 horizontal well and then the Bowers 1-25 HD) 80 acre unit, SW 1/4 SW 1/4 of section 24 and the NW $1 / 4$ NW $1 / 4$ of section 25 of Vernon Twp) was proposed to evaluate a 200 acre undeveloped prospect area adjoining the Vernon field to the east (Figure 19). The Vernon Dundee production is associated with dolomitization of the upper Dundee (Rogers City) interval. The dolomite body is defined by the existing well control to date that encompasses some 2000 acres (Figure 16). The extent of the dolomitization is considered to be fracture controlled. Immediately surrounding the dolomite trend are wells in which the dolomite is overlain by dense limestone cap rock. The thickness of the cap rock in this border area ranges upwards to 75 feet. Wells within this thickness range generally exist within $1 / 2$ mile of the dolomitized area. Further out from the dolomitized area, the cap rock thickness is 100 feet or more as regionally the 350 foot Dundee section consists predominantly of limestone in the prospect area.

\subsubsection{Prospect Background}

The Bowers 4-25 attempted to extend the Vernon field eastward. The existing well control suggests the fairway of dolomitization continued in this direction. The 200 acre prospect is rather well defined by existing Dundee penetrations with anomalously thin or no limestone cap rock These wells include the 3 Dundee oil wells on the Verette lease ( $\mathrm{SE}^{1 / 4} \mathrm{SE}^{1 / 4}, 23$ ). Drilled in 1933 , the 40-acre tract cumulated 132,558 barrels before abandonment in 1938. The Verette \#1 (NW1/4 $\mathrm{SE}^{1 / 4} \mathrm{SE}^{1 / 4}, 23$ ) was one of the strongest wells in the field, completing for 5000 BOPD natural. The 
reservoir dolomite development is apparently significant in the area of this well bore. The Verette production is the eastern most in the field to date. It is important to note the Verette \#2 (NE1/4 SE $1 / 4$ $\left.\mathrm{SE}^{1 / 4}, 23\right)$ did not encounter any limestone cap rock. This establishes upper Dundee dolomitization within 330 feet of the Bowers 4-25 HD unit boundary. Along with the Verette wells, four dry holes located on the east side of the Vernon field define the East Vernon prospect. All four wells have anomalously thin limestone cap rock sections. (refer to Figures 16 and 18). The cap rock sections penetrated in these wells are similar to the proximal wells, which immediately border the Vernon dolomite trend in its entirety. As shown on the prospect maps, the trend of upper Dundee dolomitization is interpreted to extend through the Verette lease and into parts of sections 24 and 25. Another important geological aspect of the East Vernon prospect is the fact that it is favorably positioned at the updip margin of the dolomitization. In addition, the prospect area borders the southern lateral seal and the predicted subsea elevation of the top of the Dundee reservoir at the Bowers location is even with the best wells in the field.

Expected maximum gross hydrocarbon column thickness was 45 feet. The Bowers 4-25 HD prospect was an ideal application for horizontal drilling as the technology offered an excellent method to explore for upper Dundee porosity across a large area. The intended TVD for the initial leg of the horizontal hole will be -2920 subsea. Anticipated length of the lateral is 1800 feet. Recoverable reserves for the East Vernon prospect are estimated at 1,500,000 barrels of oil utilizing a 50\% recovery factor. The reserves estimate benefits from the fact the prospect is positioned at the updip limit of the Vernon reservoir. Because the prospect is located up structure, drainage from the old wells is expected to be minimal with the oil-water contact remaining at or near -2950 subsea. For the Bowers 4-25 \#1 HD test, recoverable oil reserves were estimated to be 350,000 barrels.

\subsubsection{Location}

The Bowers 4-25 drilling unit was drilled in Phase II of this project. It is described as the 80-acre unit, SW 1/4 SW 1/4 of section 24 and the NW 1/4 NW 1/4 of section 25 of Vernon Township, Isabella County. The permit for this well, 54950, was issued on February 7, 2002.

\subsubsection{Drilling and Casing history}

The well was spudded on November 27, 2002. Total depth of $3769 \mathrm{ft}$ was reached on December 4, 2002 without significant shows of hydrocarbons. The well was plugged and abandoned on December 5, 2002.

\subsubsection{Horizontal laterals}

The Bowers 4-25 was originally planned as a north to south horizontal test but was drilled as a vertical test due to the results and costs of the State-Smock well. Directional surveys near total depth indicated a deviation of the vertical well of approximately one degree.

\subsubsection{Open hole testing, coring, mudlogging, and logging}

No drill stem testing or coring was performed in this well. 
A mudlog was recorded in the well from $2900 \mathrm{ft}$ to total depth. The top Dundee was encountered at $3710 \mathrm{ft}$ measured depth (-2910 ft subsea). Top porosity and/or top dolomite was encountered at $3764 \mathrm{ft}$ measured depth. The well began flowing water with a sour crude odor at $3766 \mathrm{ft}$. A gas increase was noted beginning around $3750 \mathrm{ft}$ measured depth but no oil fluorescence or oil cuts were seen in the cuttings.

An open hole gamma ray-neutron log was recorded in the well by Baker Hughes on December 3, 2002 (Figure 20).

\subsubsection{Completion}

No completion was attempted due to the poor hydrocarbon shows.

\subsubsection{Comparison of Actual Results vs. Predicted}

The Bowers 4-25 well was originally planned as a multi-lateral well to probe for bypassed hydrocarbons, but after the State Smock came up dry, the drilling strategy was changed back to include a vertical probe well. When the Bowers well failed to establish a viable production interval in the Dundee, and the dolomite came in 14 feet below the oil-water contact, the well was abandoned. The surface geochemistry program came off as planned and suggested a marginal well. In this case, the actual results produced a better result than the original proposal in that the cost of an expensive lateral well was avoided. 


\subsection{CONCLUSION}

\section{DOE Field Demonstration Case History and Well Summary: VERNON FIELD, Isabella County, Michigan}

The State Smock well has provided us with several lessons, the most important being that in drilling old fields like Vernon it is best to begin with a drilling program that includes a vertical test well to verify the presence of a pay zone, then follow with a horizontal well with multi-laterals. In the case of the first demonstration well, the State Smock, no vertical well was drilled and the first lateral drilled encountered a shale plug that was avoided with the second lateral. A vertical well or a single-lateral horizontal well would probably have established the absence of a pay zone and avoided the cost of a lateral. In the second demonstration well, the Bowers 4-25, a vertical well was drilled and when it failed to show a pay zone the well was abandoned. In both cases, the surface geochemistry indicated marginal plays.

It has also been learned that natural fractures may play a key role in the production of these carbonate reservoirs. Isolating productive regions from water conductive fractures may be an important issue in recovering significant bypassed reserves. In addition, formation damage due to pulverized cuttings and drill pipe abrasion appears to be a prevalent issue within porous zones, even after relatively short periods of lateral drilling exposure. An additional lesson is that geochemical surveys, particularly microbial, are worthwhile in these fields. Microbial surveys are relatively inexpensive and in this case appeared to provide reliable guides to the presence or absence of hydrocarbons. Finally, our knowledge of the state of the upper Dundee Formation greatly increased as a result of the drilling of the State Smock. We now feel that the top of the Dundee near the Vernon Field represents an exposed karst surface spotted with deep sinkholes filled with shale, perhaps similar to modern day topography around Tampa, Florida. 


\subsection{REFERENCES}

Fitzgerald, P. E. and W. A. Thomas, 1932, The occurrence of fluorite in the Monroe Formation of the Mount Pleasant oil pool: Papers of the Michigan Academy of Science, Arts and Letters, v. 16, p. 415-420.

Horvitz, L., 1985, Geochemical exploration for petroleum: Science, v. 229, p. 821-827.

Jones, V. T., and R. J. Drozd, 1983, Predictions of oil or gas potential by near-surface geochemistry: AAPG Bull., v. 67, p. 932-952

Newcombe, R. B., 1932, Oil and gas fields of Michigan: Michigan Geologic Survey Publication 38, Geological Series 32, p. 165-167. 


\subsection{FIGURES}




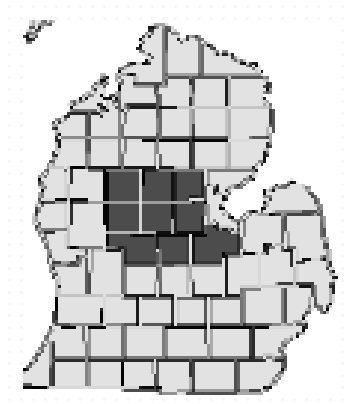

\section{MTSSAUKEE}

Riverside

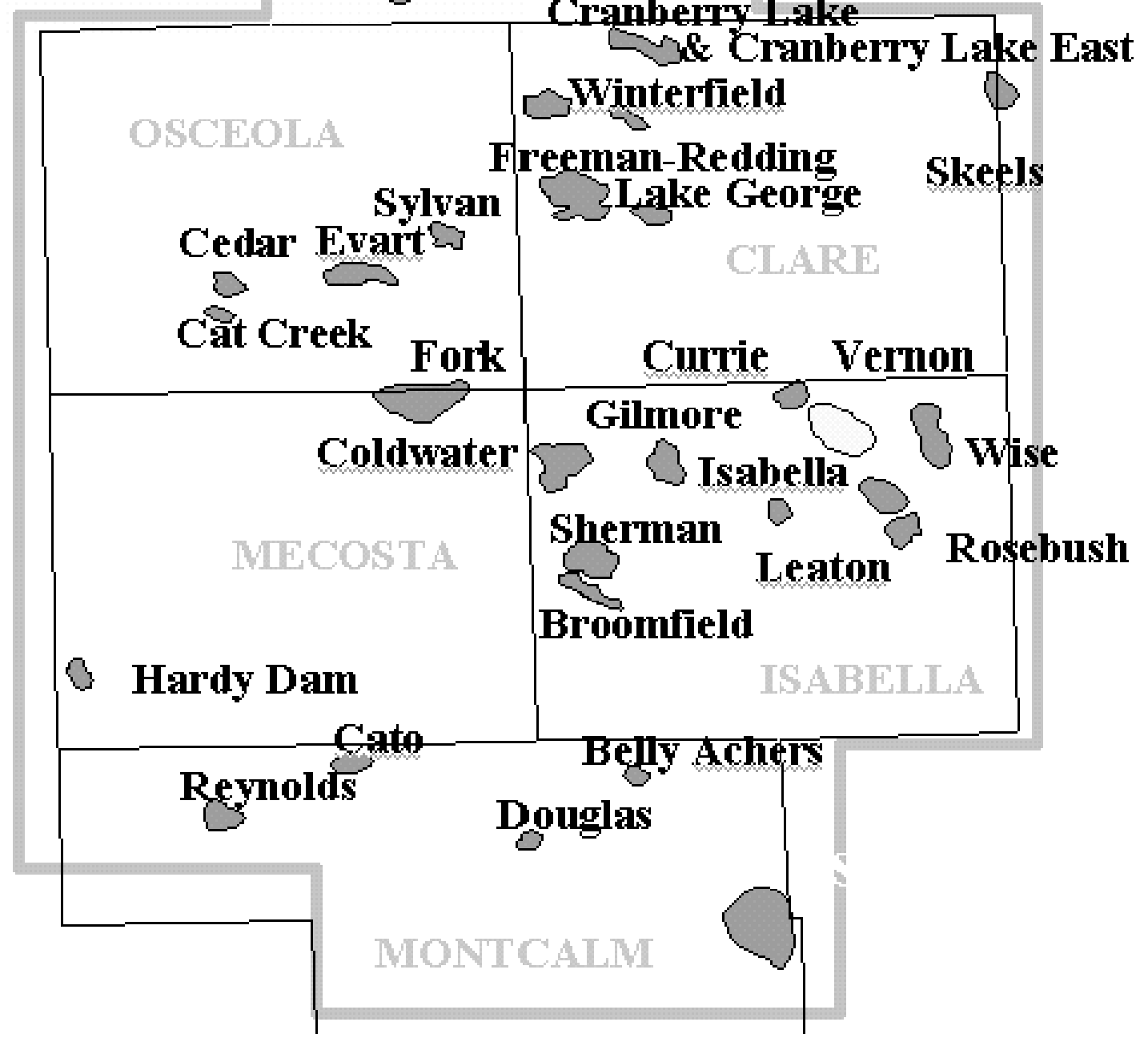

Figure 1. Six county index map for central Michigan showing the location of Vernon Field and other Dundee Fields. Vernon Field is located in north central Isabella County. Noth is toward the top of the page. Inset map shows location in lower peninsula of Michigan. 


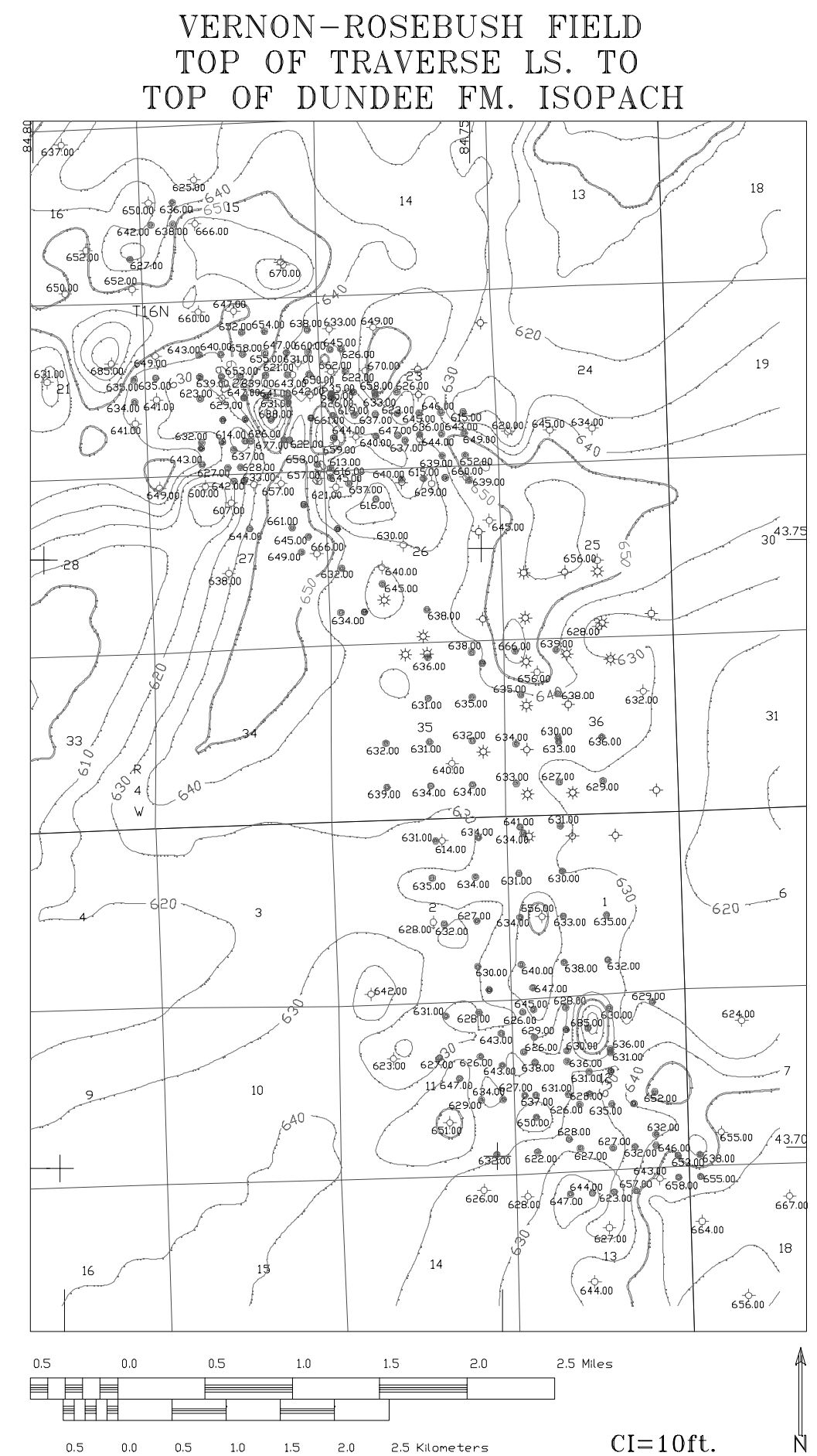

Figure 2. Index map showing Vernon-Rosebush Field area and isopach map from top of Traverse to top of Dundee Formation (interval overlying the productive interval); contour interval $10 \mathrm{ft}$. Green well symbols are oil wells producing from the Dundee/Rogers City or Dundee/ Richfield and red well symbols are gas wells producing from the shallower Stray sand. Rectangle indicates Vernon Field. 


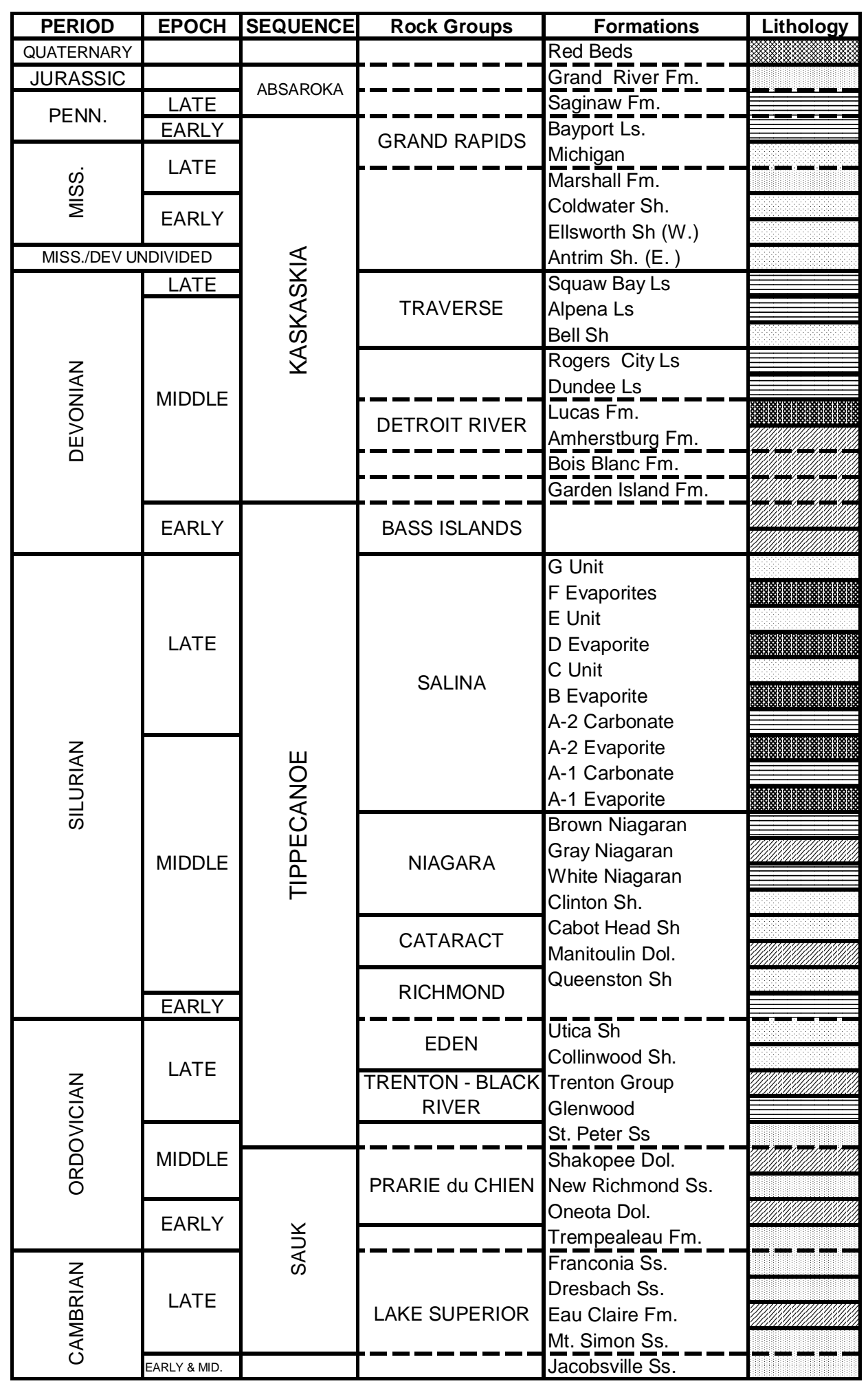

Figure 3. Generalized stratigraphic column for Michigan Basin. 


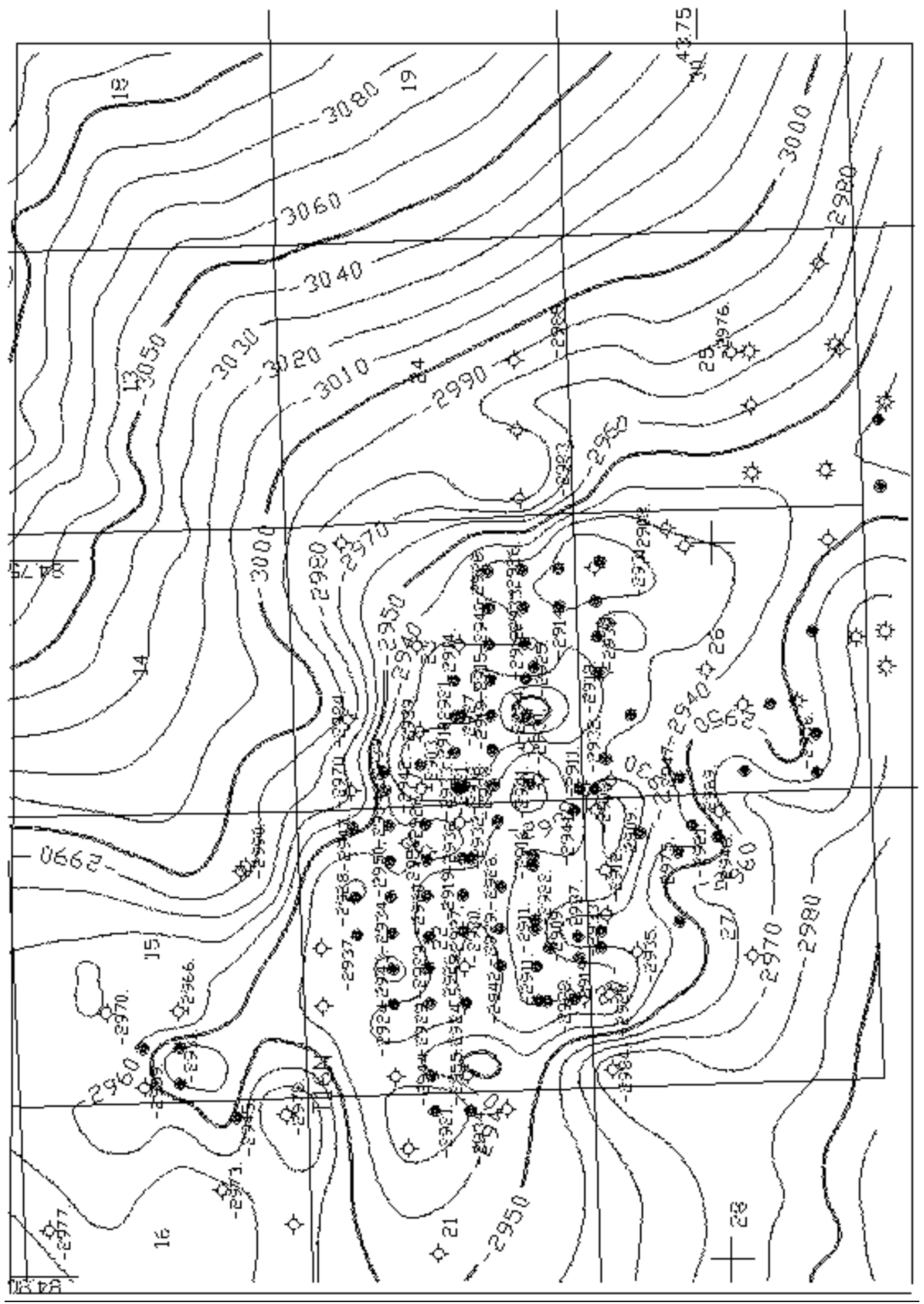

Figure 4. Structure map overVernon Field showing approximately $30 \mathrm{ft}$ of structural closure; contour interval $10 \mathrm{ft}$. Black dashed line shows location of Mission Road geochemical profile. Green well symbols are producing wells or abandoned producers. Rectangles are one square mile sections. North is to the left. 


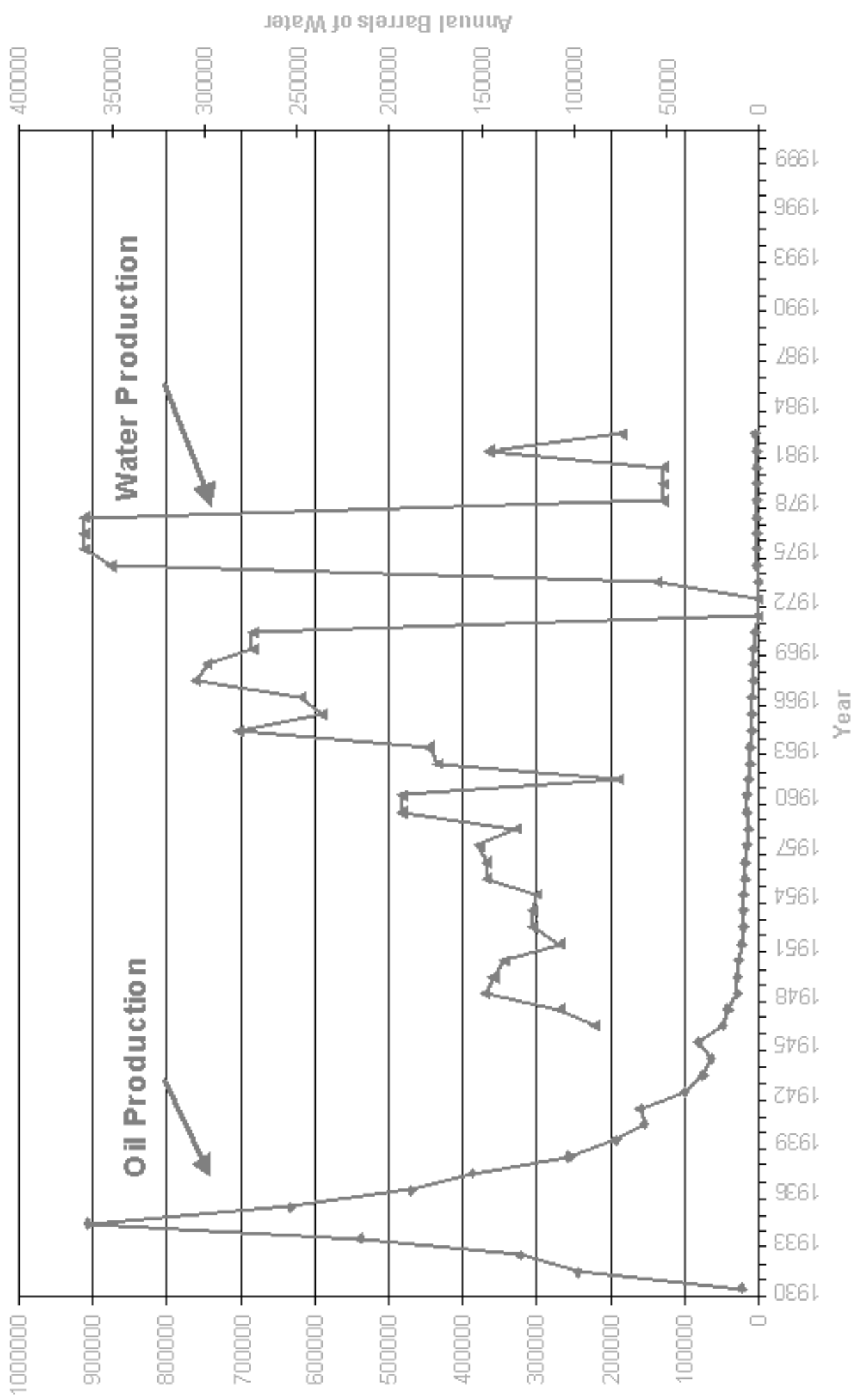

Figure 5. Annual oil and water production for the Vernon Field 1930 through 1983. 


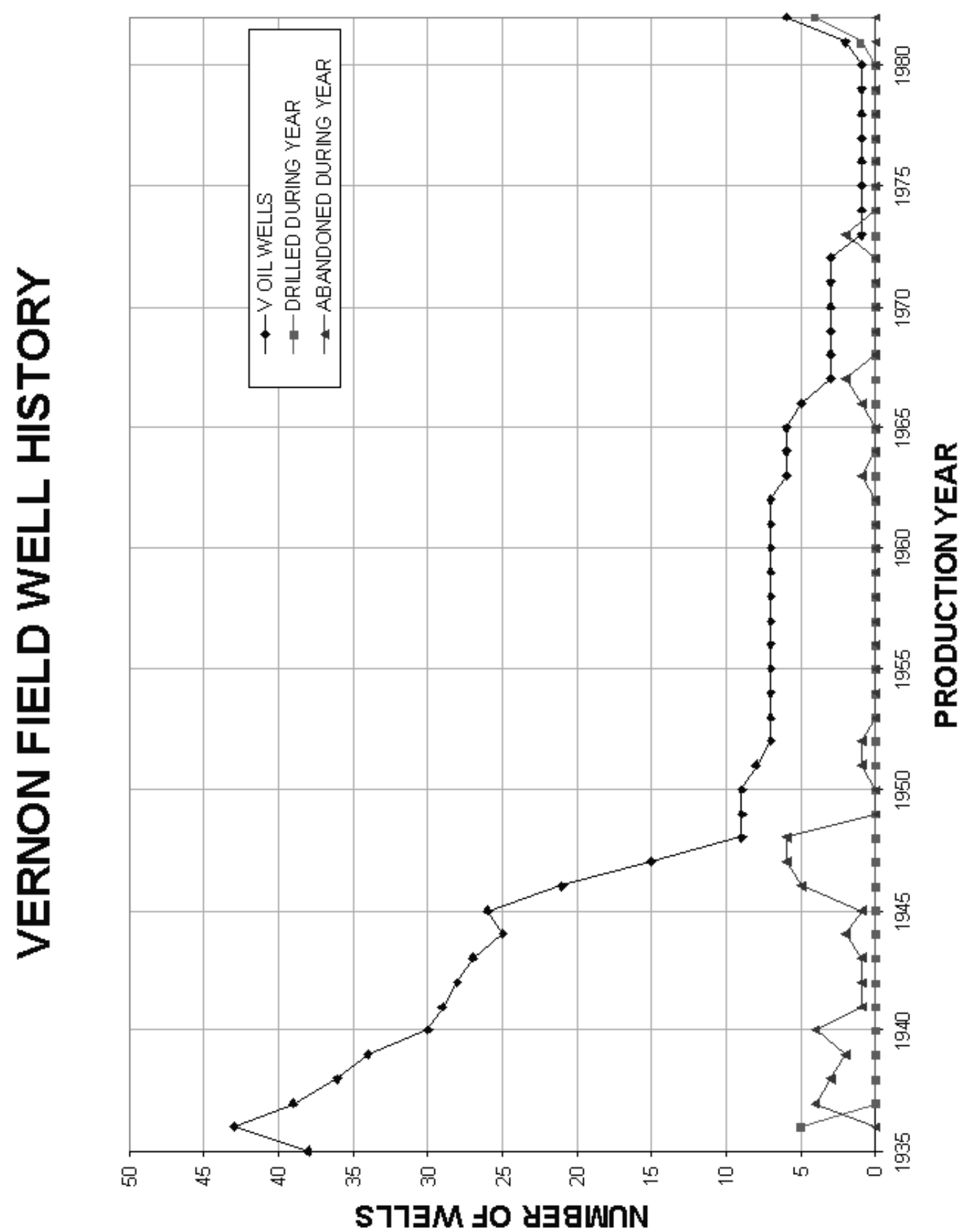

Figure 6. Annual drilling history for theVernon Field 1930 through 1983. 


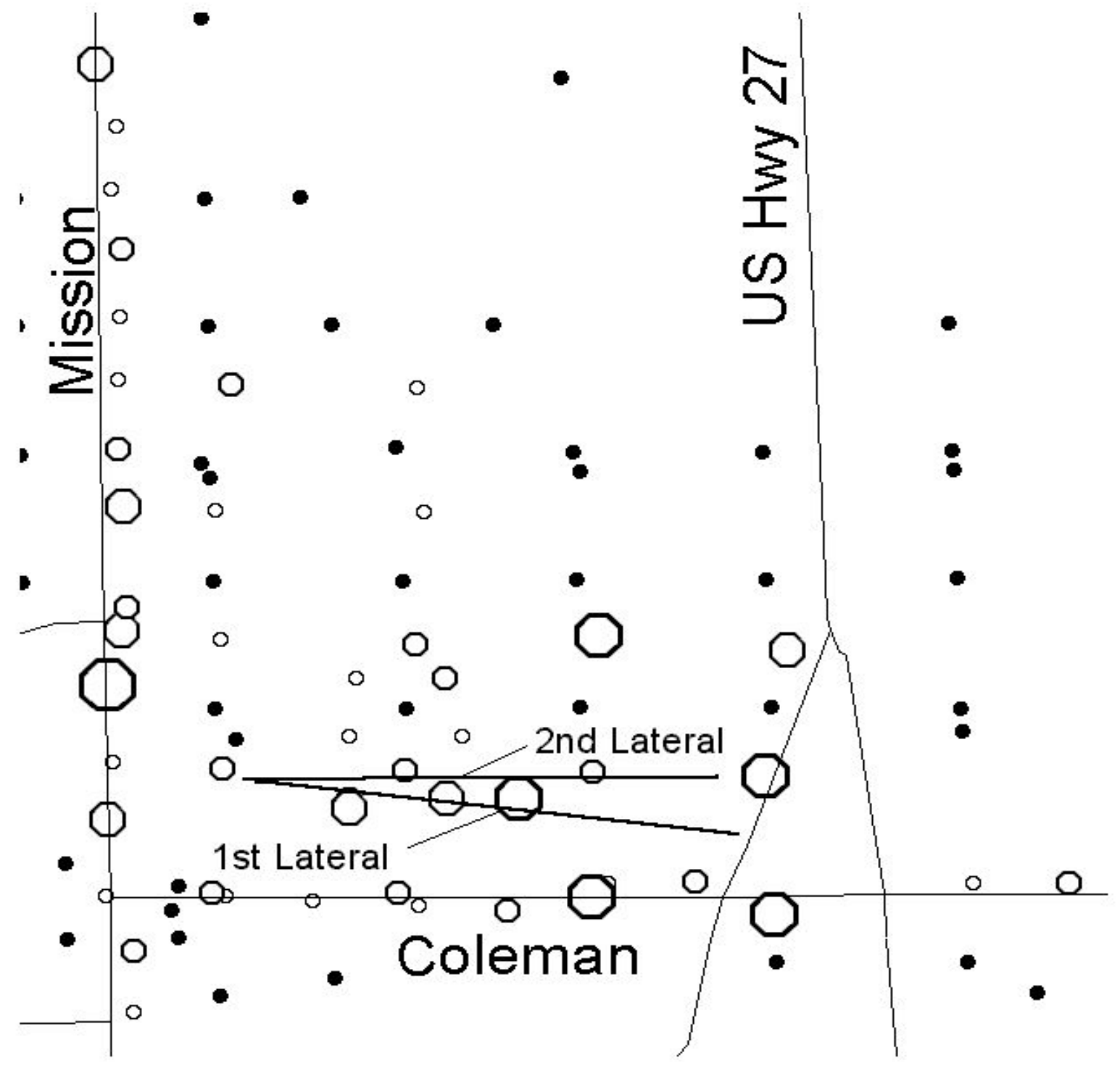

Figure 7. Approximate location of two laterals from StateVernon and Smock well. Solid black circles are oil wells and open circles are microbial sample points. The size of the open circles is proportional to the geochemical signal. 


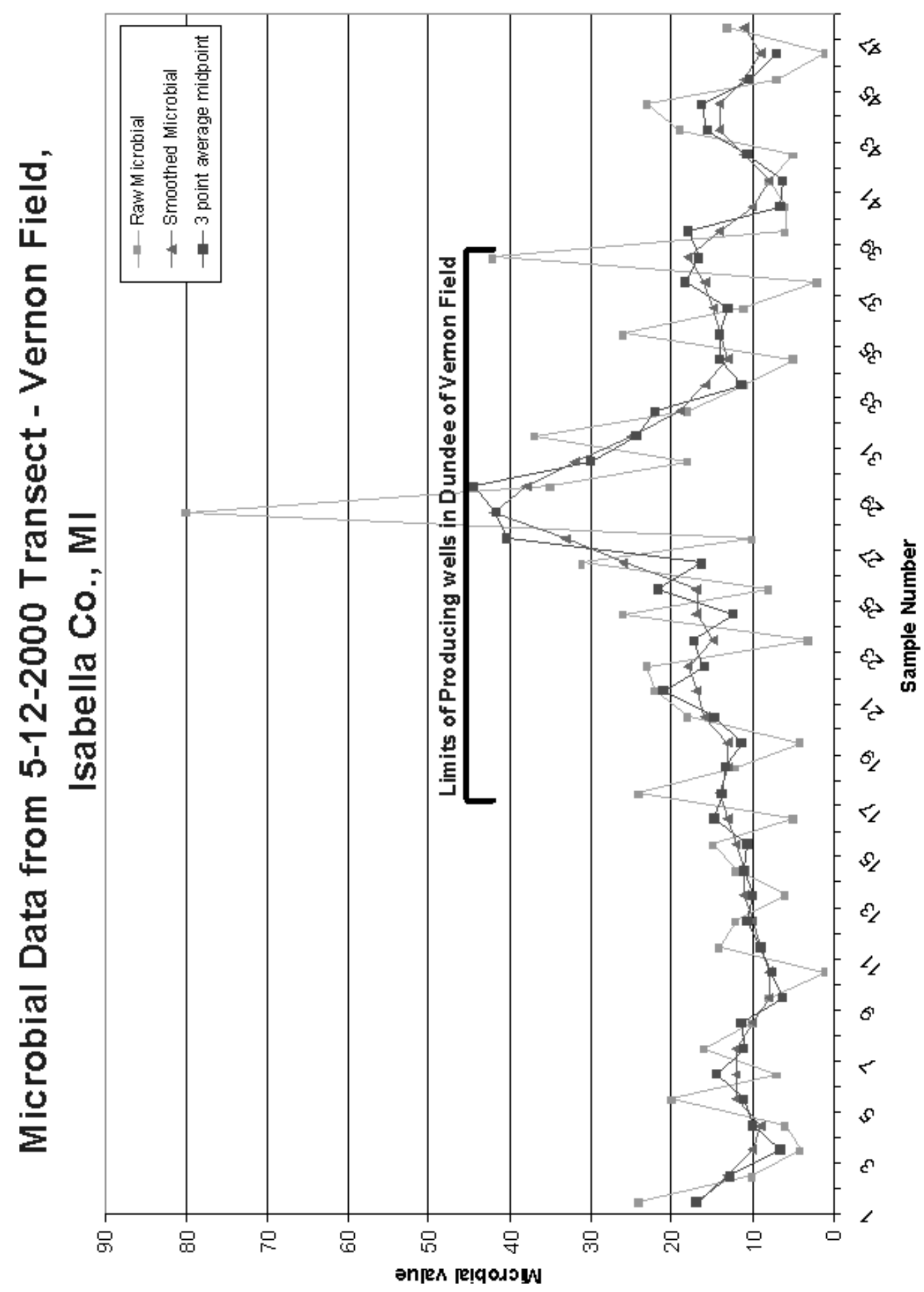

Figure 8. Mission Road Microbial data profile showing ray, smoothed and three-point averages of microbial data. North is toward the top of the page. 


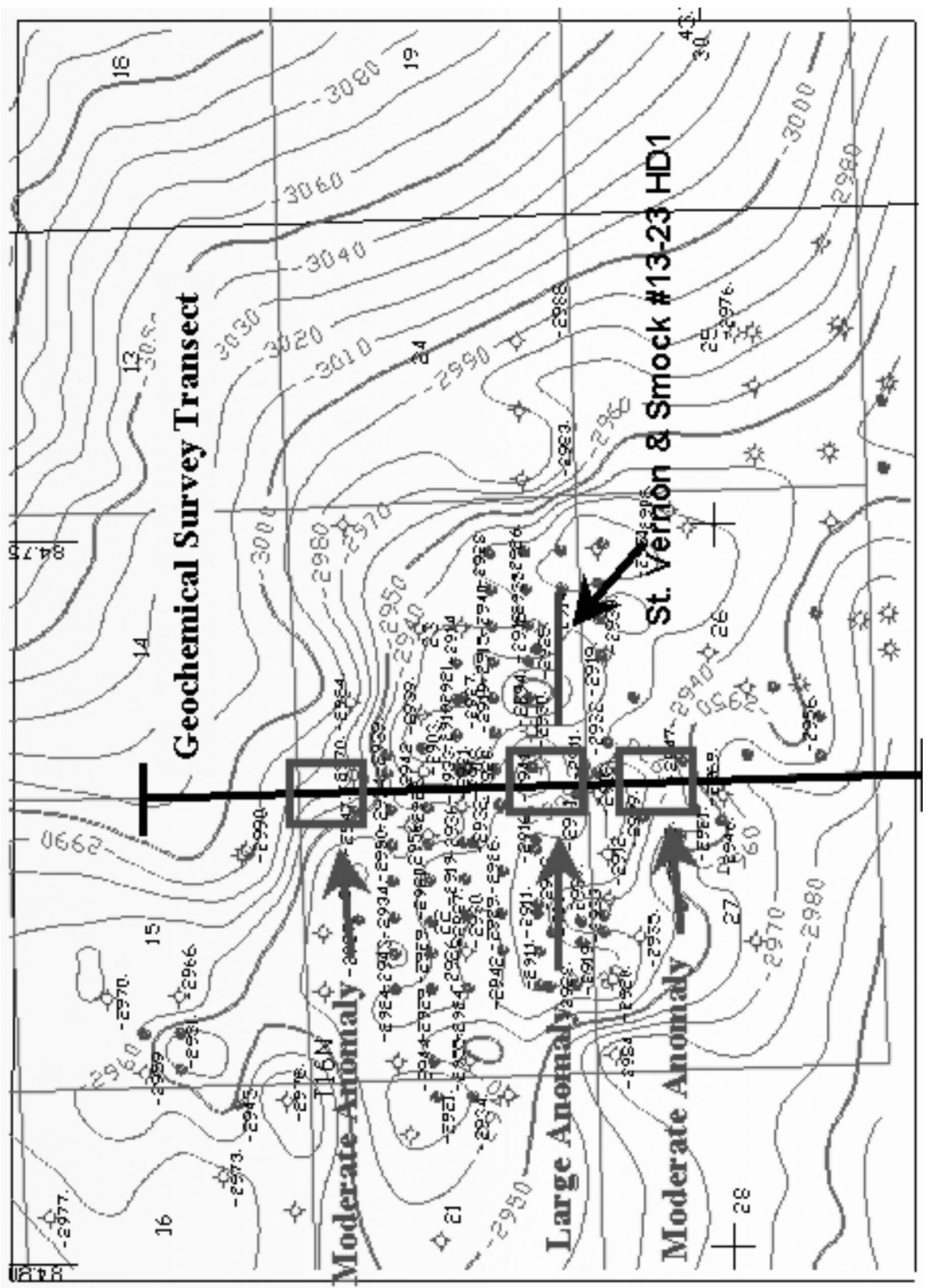

Figure 9. Structure contour map showing location of geochemical anomalies along the Mission Road profile. The location of the State Vernon and Smock well is also shown. Contour interval is $10 \mathrm{ft}$ and north is to the left. 


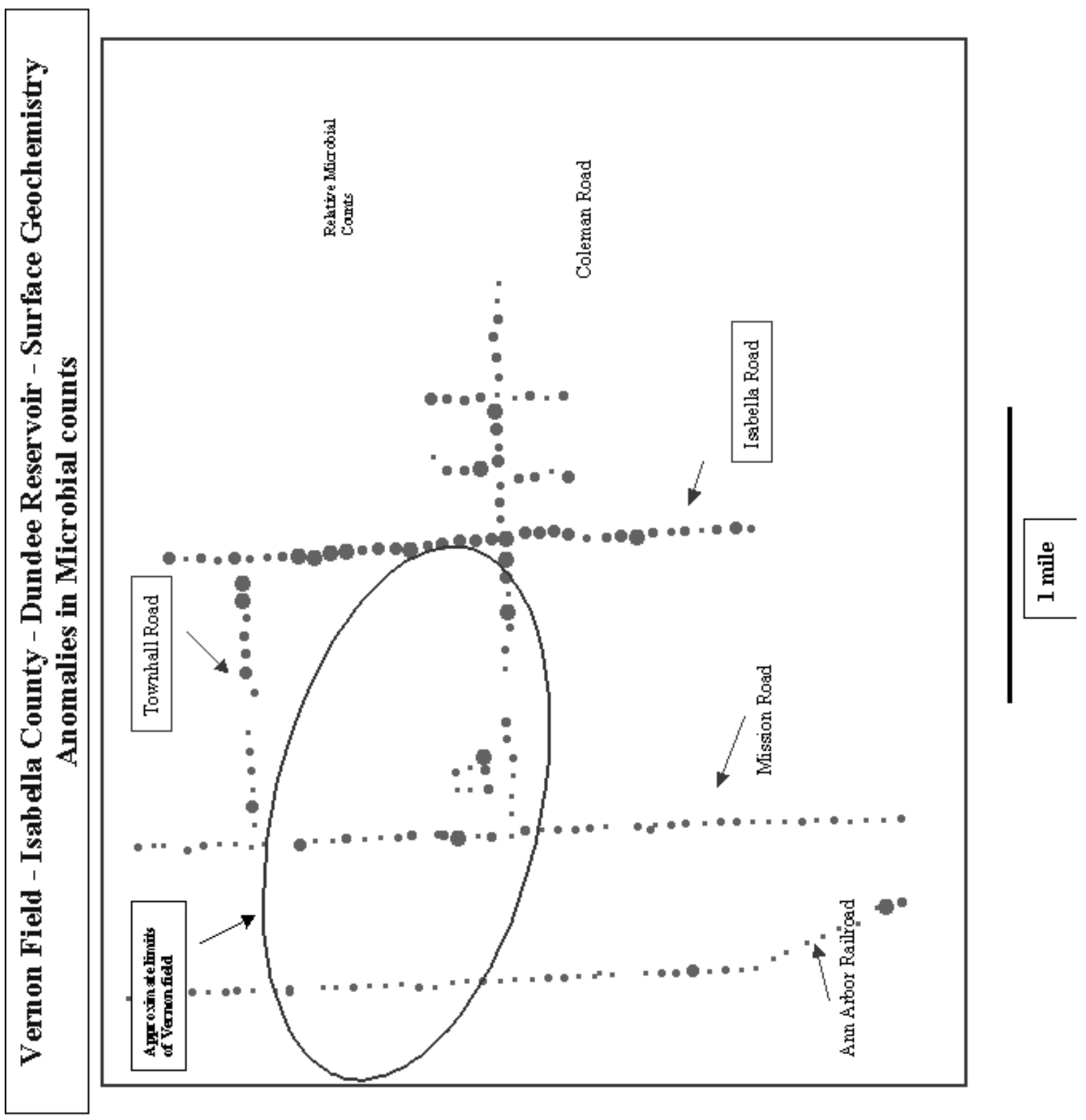

Figure 10. Vernon Field area map showing microbial geochemical profiles. Bubbles are proportional to size of anomalies. North is to the right. 

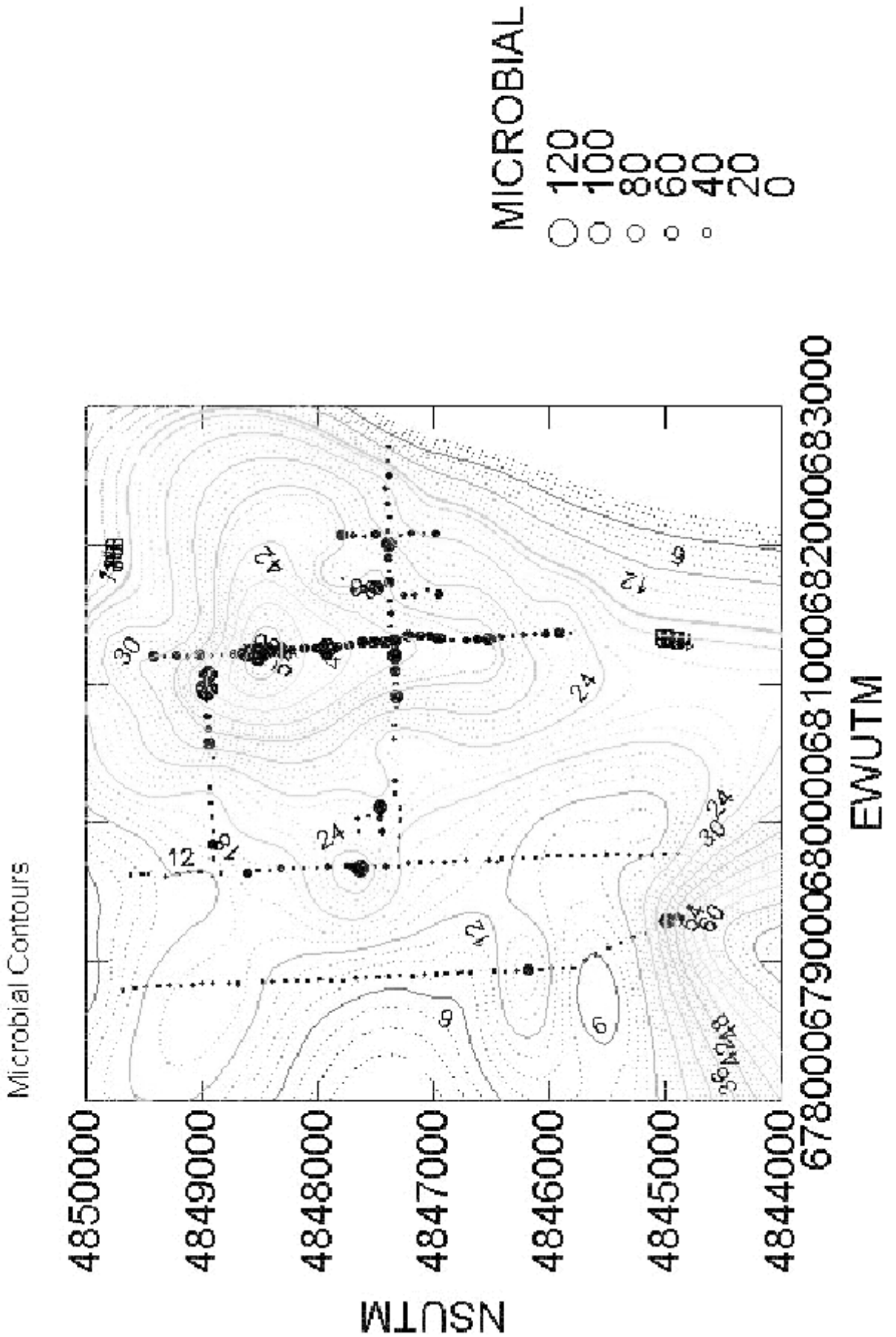

Figure 11. Vernon Field area map showing contoured microbial geochemical profiles. Bubbles are proportional to size of anomalies. Contour interval is two units. North is to the right. 


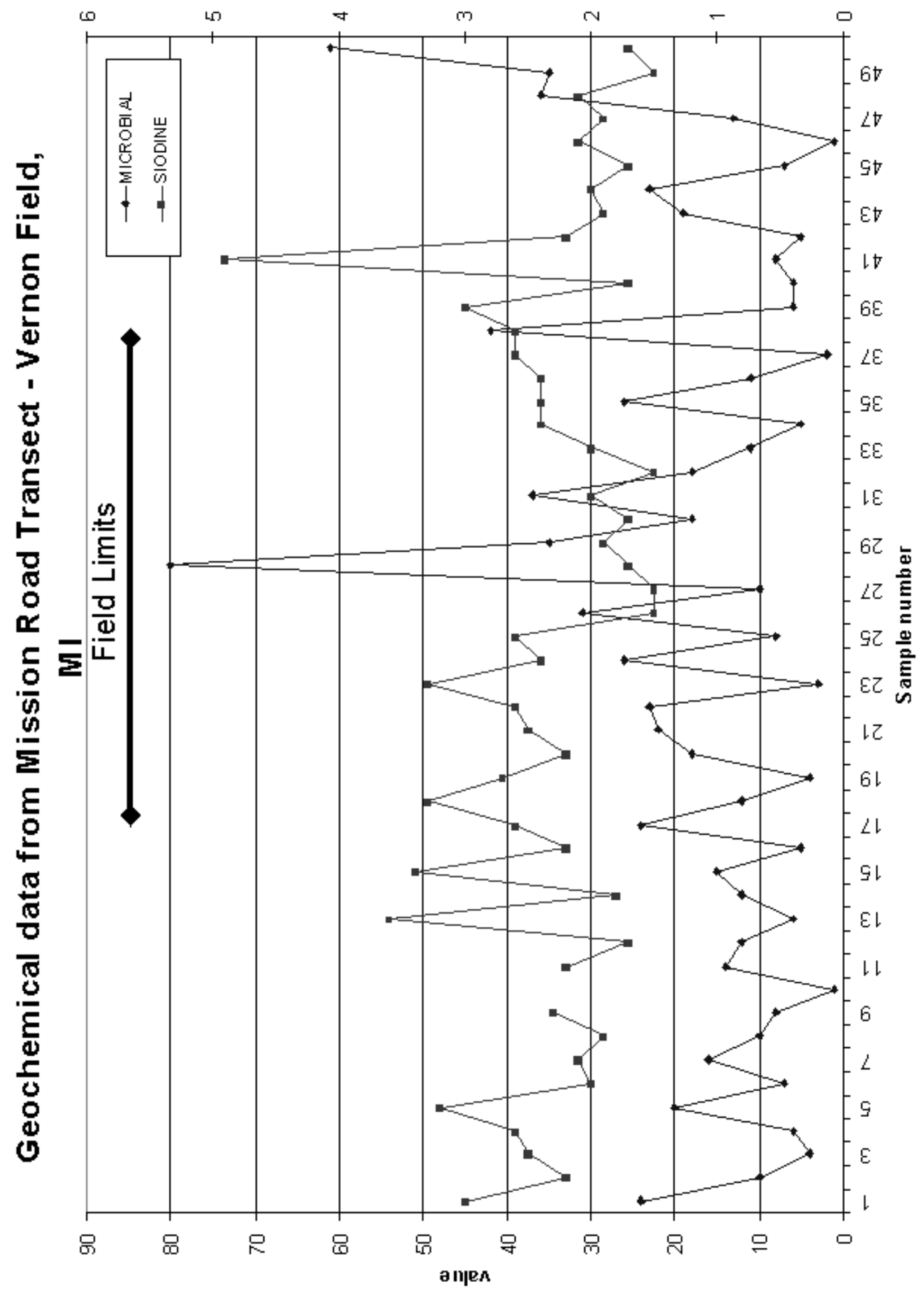

Figure 12. Iodine and microbial data for Mission Road profile. 


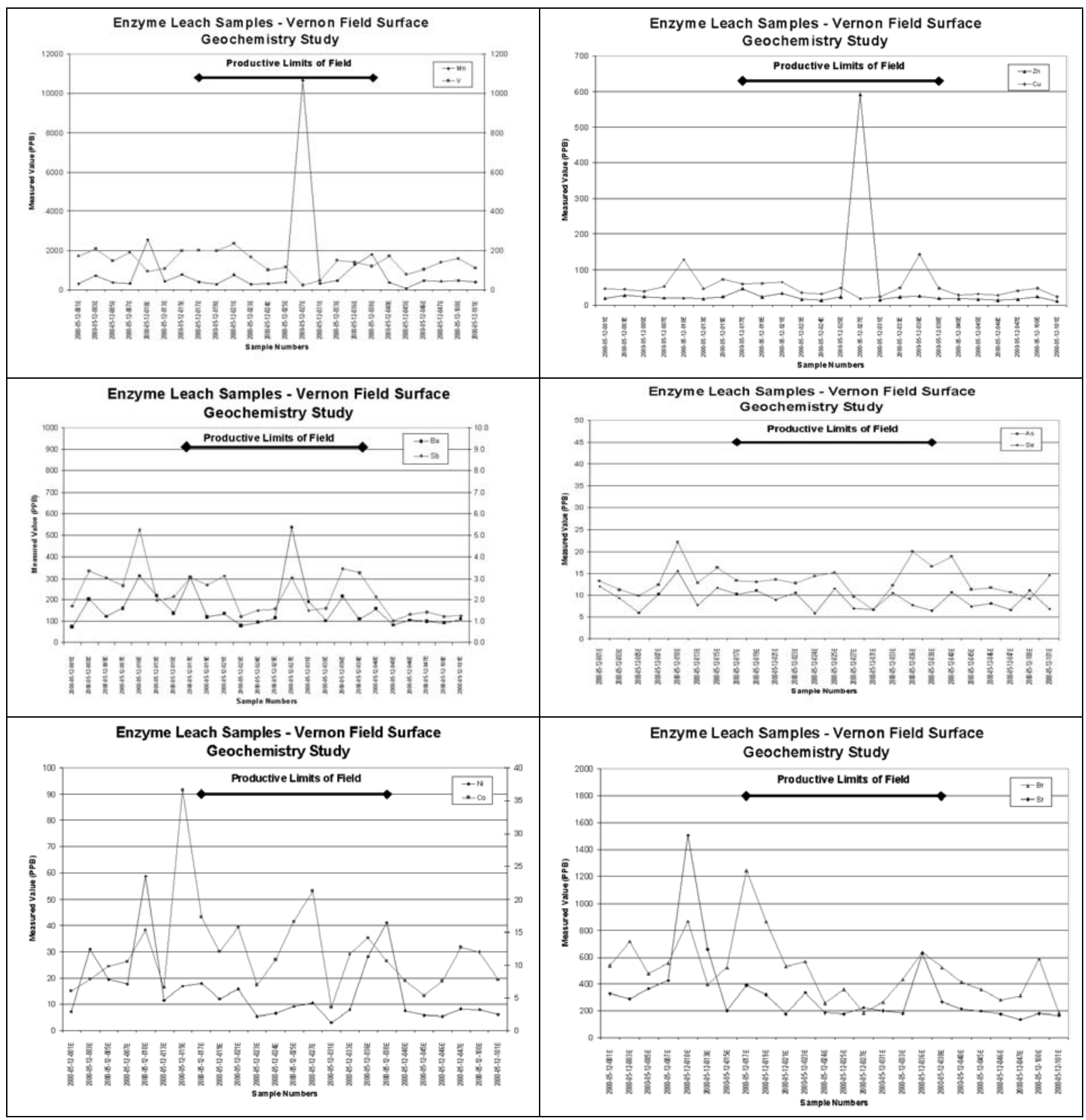

Figure 13. Enzyme leach trace element Mission Road profiles for $\mathrm{Mn}$ andV, $\mathrm{Zn}$ and $\mathrm{Cu}, \mathrm{Ba}$ and $\mathrm{Sb}, \mathrm{As}$ and $\mathrm{Se}, \mathrm{Ni}$ and $\mathrm{Co}$, and $\mathrm{Br}$ and $\mathrm{Sr}$. 


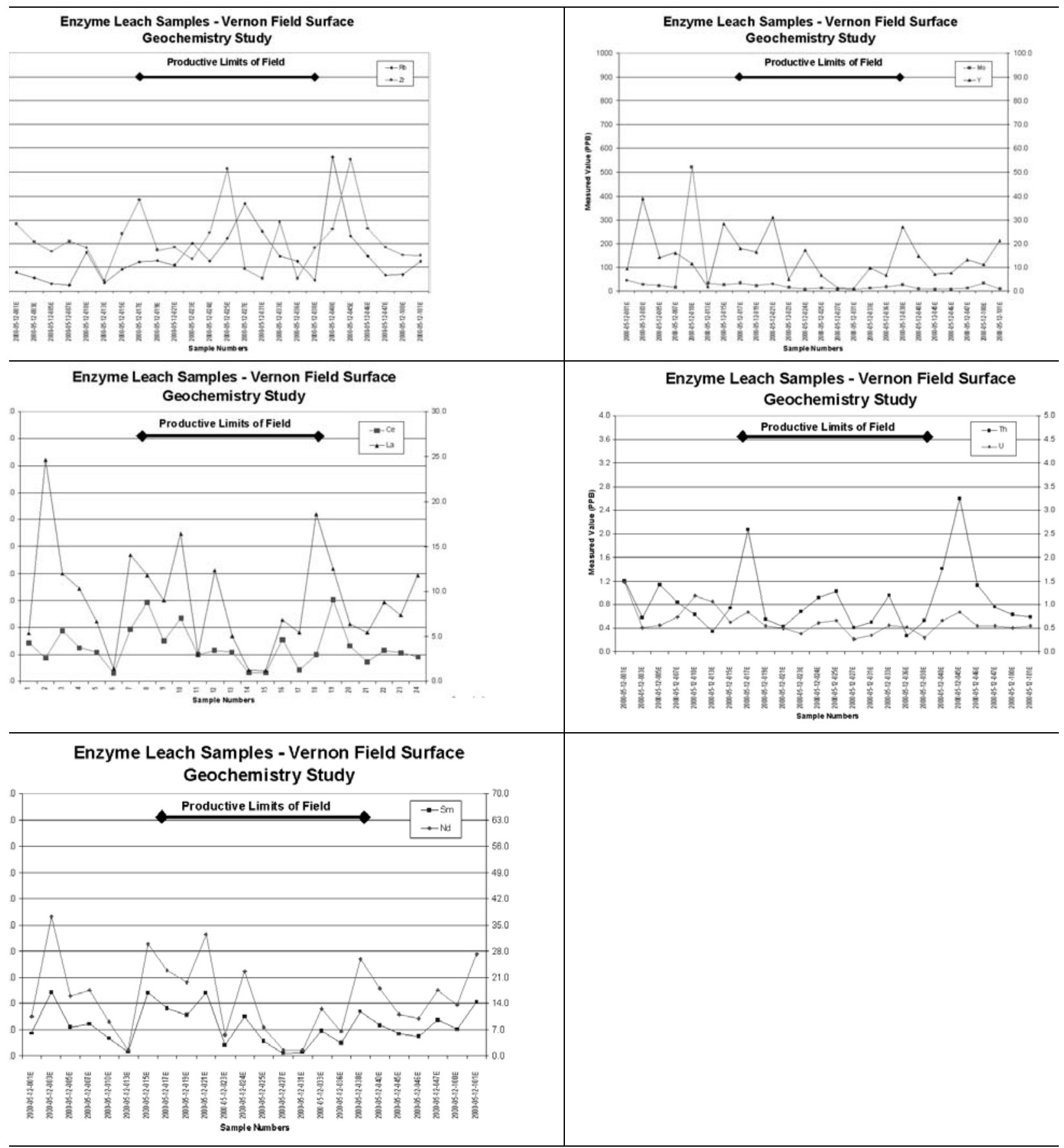

Figure 14. Enzyme leach trace element Mission Road profiles for $\mathrm{Rb}$ and $\mathrm{Zr}$, Mo and $\mathrm{Y}$, Ce and $\mathrm{La}$, Th and $\mathrm{U}$, and $\mathrm{Sm}$ and $\mathrm{Nd}$. 


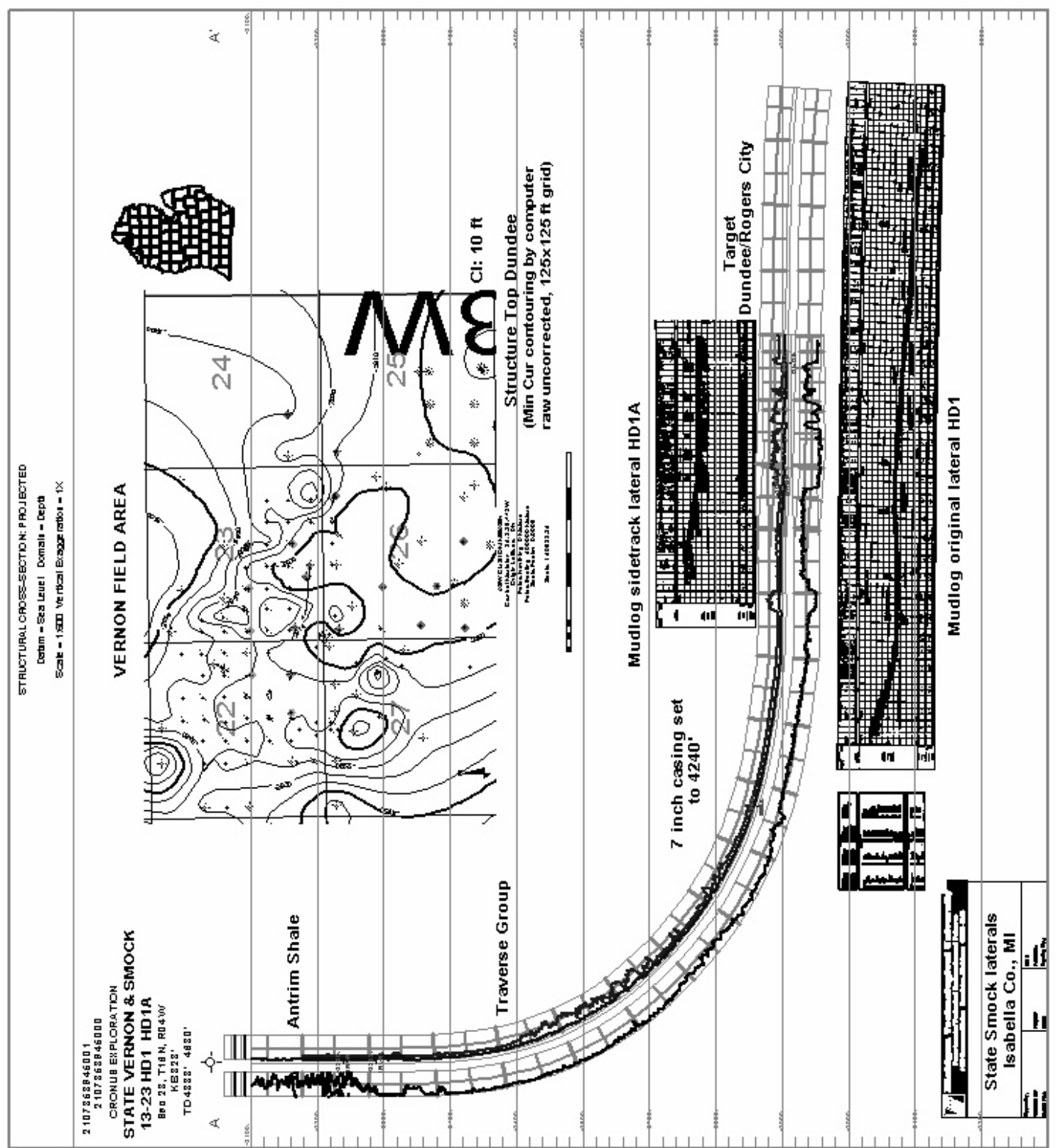

Figure 15. State Vernon \& Smock 13-23 \#HD1 and \#HD1A well path, curve, and horizontal laterals. Log curves are gamma ray on left or bottom and neutron curve on right or top in log track. Mudlog images shown along path. Inset map shows location of well and laterals in Section 23 , in the southwest quarter and structure on the top of the Dundee. 


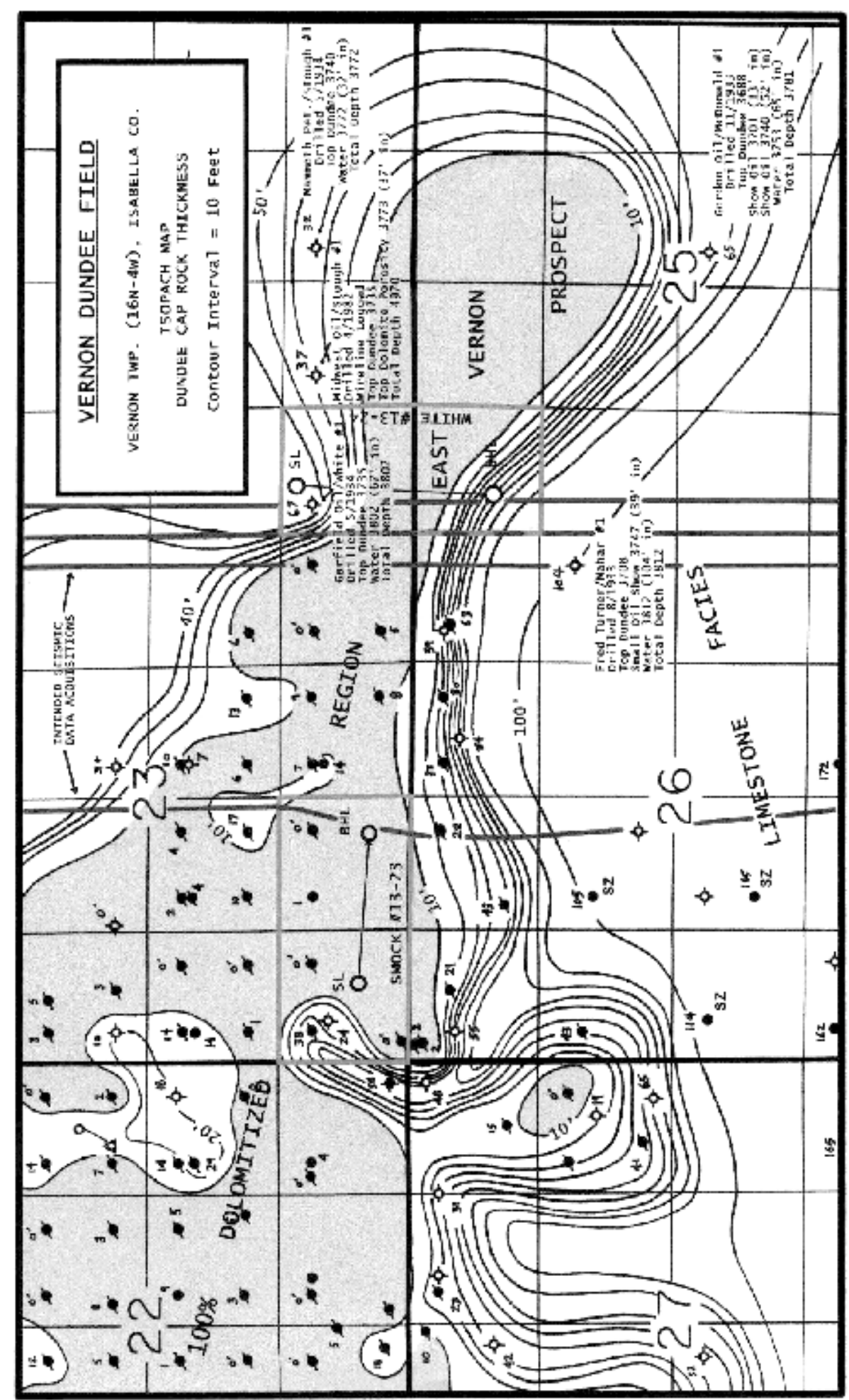

Figure 16. Dundee cap rock isopach map showing pre-drill geology for theVernon Field and the location of the State Smock well. North is to the left. Prepared by Eric Taylor. 


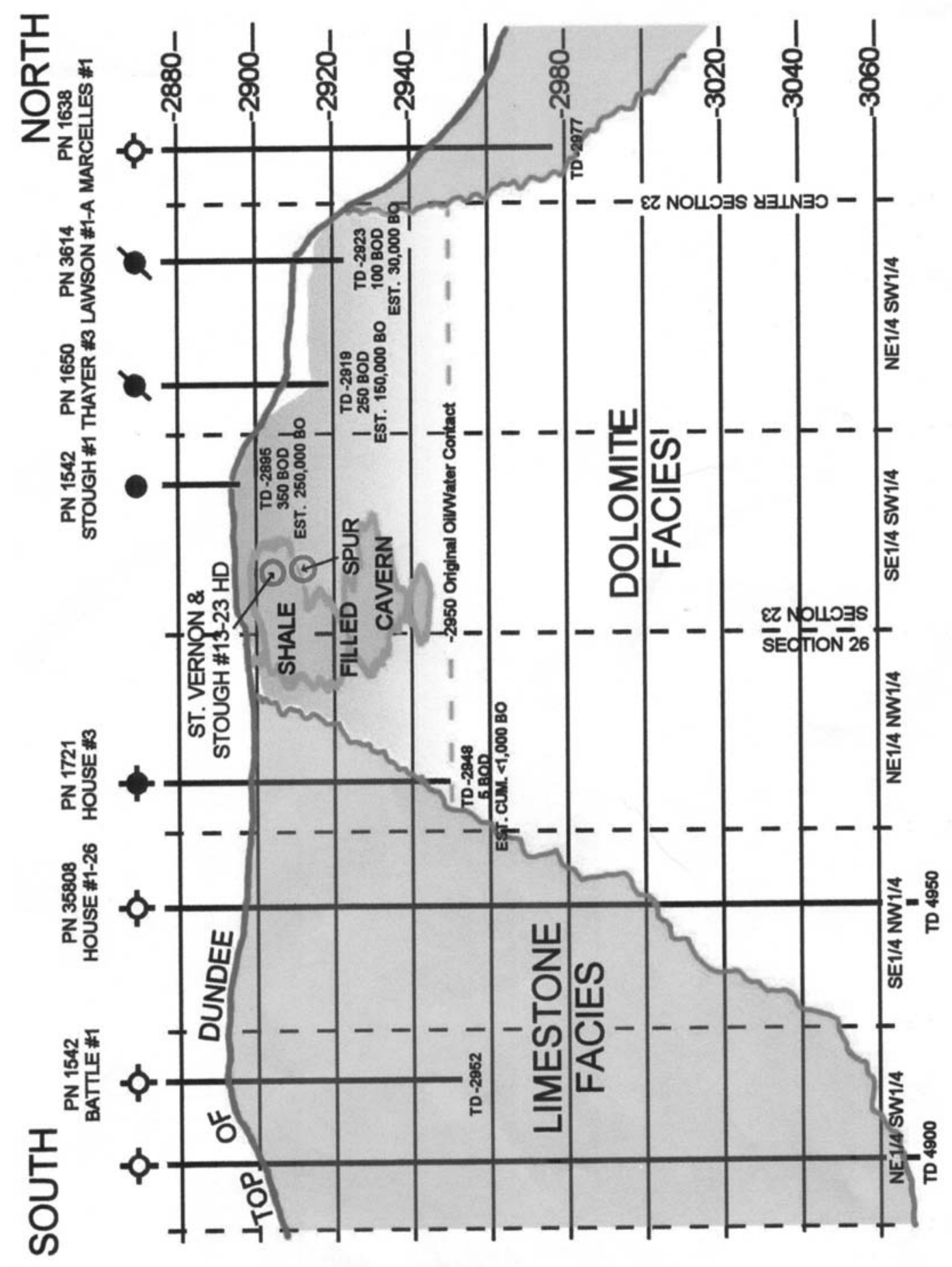

Figure 17. State Vernon and Smock post drill well bore schematic. See Figure 16 for location of cross section (interpretation by Eric Taylor). 


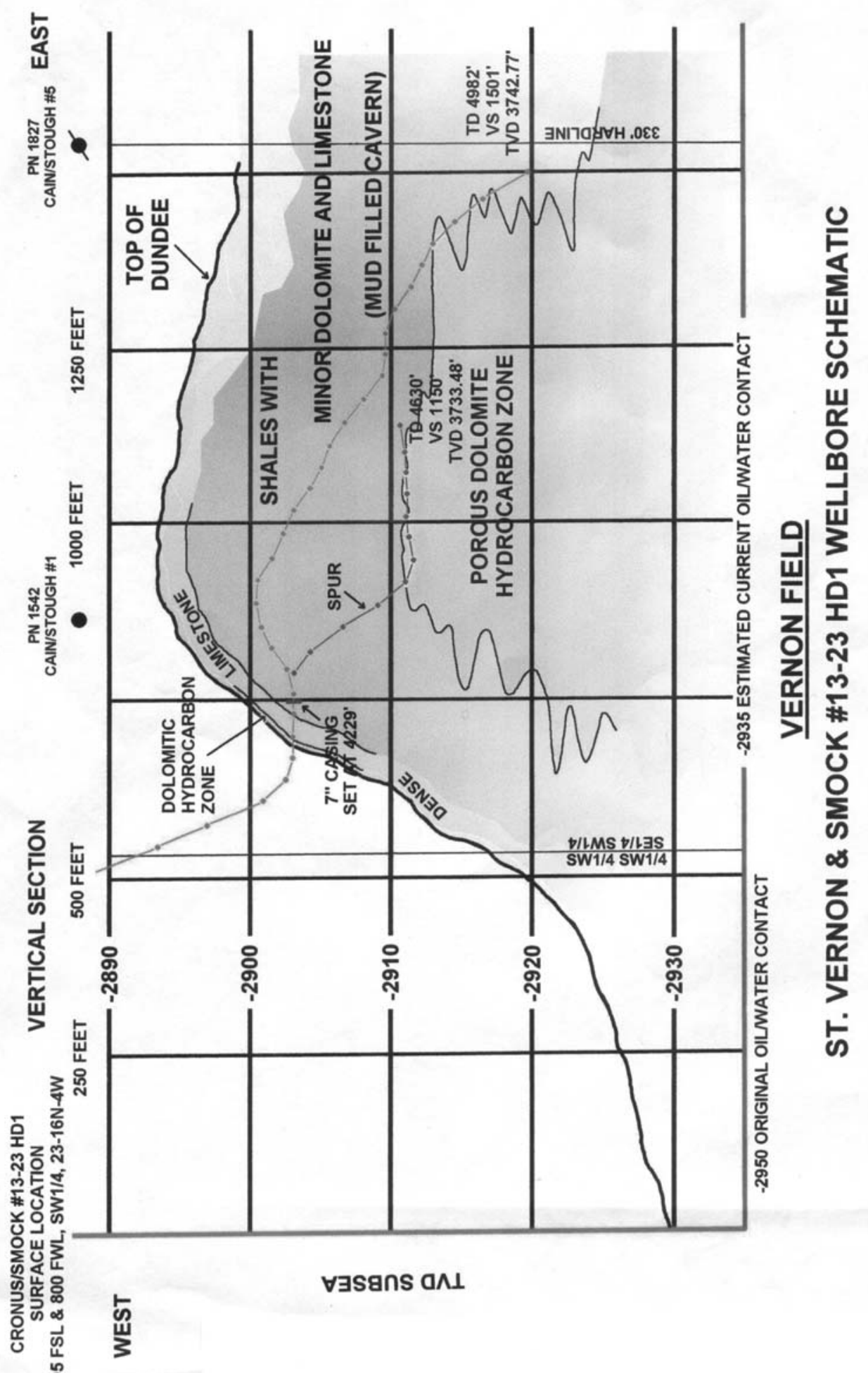

Figure 18. State Vernon and Smock post drill well bore schematic showing interpreted path of laterals (interpretation by Eric Taylor). 


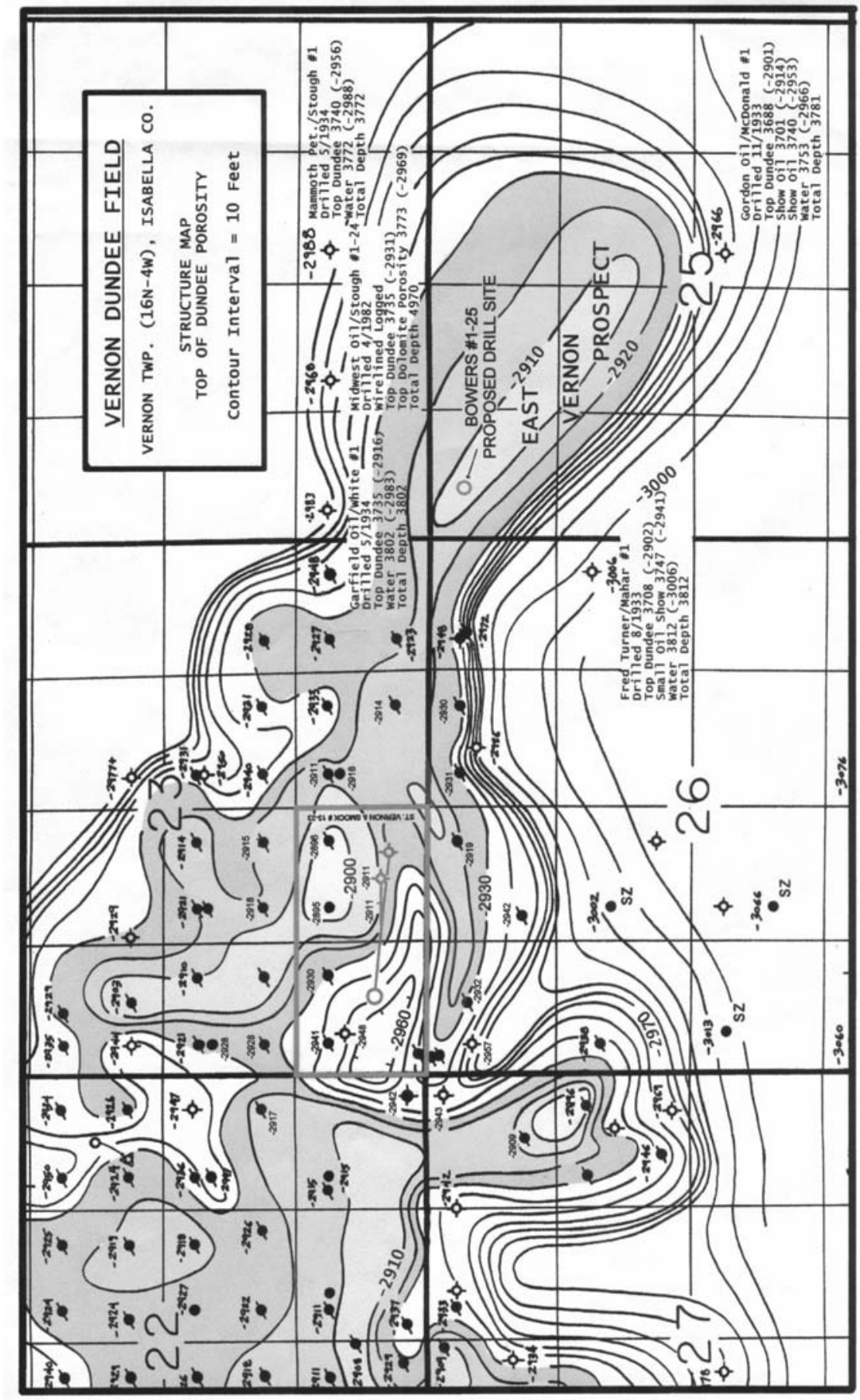

Figure 19. Structure map on top of Dundee porosity showing location of Bowers 4-25 well. The State Vernon and Smock well bore and lateral paths are also shown. (interpretation by Eric Taylor). 


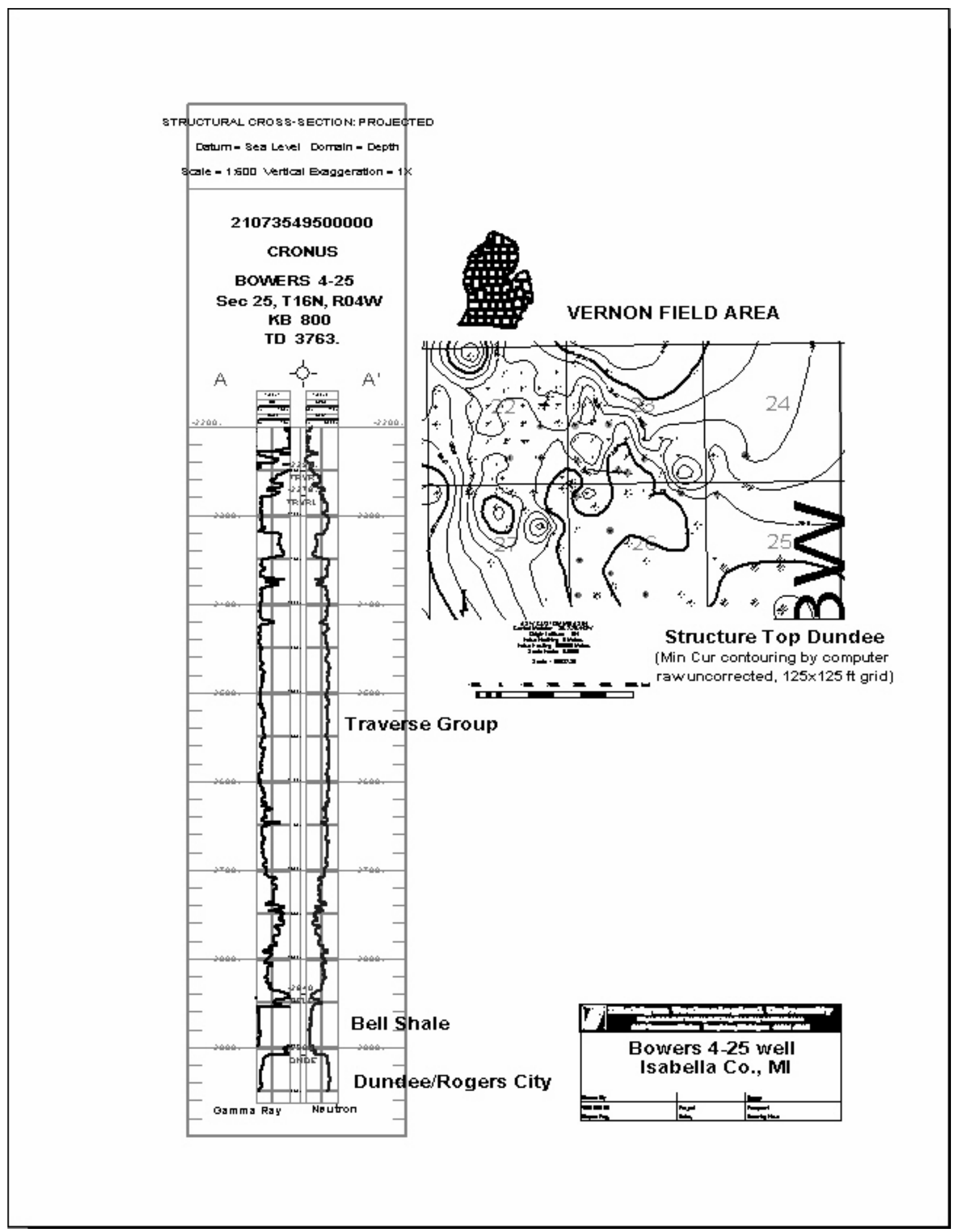

Figure 20. Bowers 4-25 well log. Gamma ray shown on left and neutron curve on right. 


\subsection{APPENDIX 1 - AAPG papers presented on Vernon Demonstration}

\subsection{AAPG Eastern Meeting, Kalamazoo, MI 2001 \\ Results of Surface Geochemistry Survey over the Vernon Field, Isabella County, MI}

BORNHORST, T.J., WOOD, JAMES R., and CHITTICK, S.D., Michigan Tech. Univ., Houghton, MI; HARRISON, W.B., BARNES, D., Western Michigan Univ., Kalamazoo, MI

Four surface geochemical techniques have been tested at the Vernon Field in support of a demonstration project partially sponsored by the U.S. Department of Energy to detect and recover bypassed oil. The techniques included surface iodine, enzyme leach, microbial and soil gas. The most extensive sampling (350+ samples) was for the microbial oil survey technique in which microorganisms are cultured from soil taken $20 \mathrm{~cm}$ beneath the surface. Results from a smaller number of iodine samples (collected from soil within an inch of the surface), headspace soil gases (collected from 1 meter beneath the surface) and selectively extracted trace elements (from the top of the B-horizon) and soil gas hydrocarbons (extracted from soil of the top of the B-horizon) will be presented as well.

The detection of subsurface accumulation of oil and/or gas by surface geochemical techniques is based on microseepage of reservoired hydrocarbons to, the surface and has been used elsewhere in combination with other data to reduce drilling risk. Except for the enzyme leach techniques, the surface geochemical signal recorded is transient (i.e. not cumulative) and will respond to changes in the reservoir. Only transient techniques are useful to detect by-passed oil. The microbial anomaly was apical while the others are best interpreted as edge anomalies or halos around the target.

The initial collection of geochemical samples was completed during the summer of 2000 and sampling will be continued during the summer of 2001. The challenge with all of the surface geochemical techniques is definition of anomalies and their interpretation. The cause of the surface geochemical anomalycan be from a variety of depths beneath the surface. The initial results demonstrate that hydrocarbon microseepage from the Dundee reservoir is detectable by surface soil geochemical techniques. 


\title{
7.2 AAPG Eastern Meeting, Kalamazoo, MI 2001 \\ Results of Recent Drilling at Vernon Field, Isabella County, MI. and A Geologic Model for the Top of the Dundee Fm.
}

\author{
WOOD, J. R, BORNHORST, T. J. AND CHITTTICK, S. D. Michigan Tech. Univ., Houghton, \\ MI, HARRISON, W. B., BARNES, D. Western Michigan Univ., Kalamazoo; MI, QUINLAN, W. \\ Cronus Energy LLD, and TAYLOR, E., Consultant, Traverse City, MI
}

\begin{abstract}
A horizontal well with dual laterals was drilled at Vernon Field in the fall of 2000. This well was designed to probe the field for bypassed oil and was sited based on data from previous wells. The initial lateral penetrated the Dundee Formation at -2905 feet subsea and continued approximately due East for 1501 feet, mostly in hard shale (plug?) with no hydrocarbon shows. The second lateral was offset to the Northeast and about 9 feet higher in the section. This lateral encountered good shows and good reservoir rock but efforts to bring it on production failed. The well was plugged and abandoned January 5, 2001.
\end{abstract}

The main reason for the failure of the well to produce was excessive water production probably due to two main causes: (1) water introduced into the lateral via fractures, and (2) a higher water table than anticipated due to efficient previous production. If fractures were the reason, then serious doubt is cast on the use of laterals to produce bypassed oil from fields of this type. Although the use of a multi-lateral well did allow us to probe the formation for good reservoir rock, the same strategy may have doomed the effort to put the well on production by increasing the chances of cutting water-bearing faults or fractures. On the other hand, a vertical well sited over the shale plug encountered in the first lateral would have likely failed too.

A geologic model was constructed for Vernon Field that takes into account the lithologies encountered in this well. The basic model is that the first well drilled into a large shale plug which is interpreted as either a mud-filled sinkhole originally formed on the surface of karsted Dundee limestone or a shale-filled low on a similarly exposed karstic surface. It appears that the dolomitization was a hydrothermal event following karstification, either subaerially or submarine. 


\subsection{APPENDIX 2 - Report by Task}

\subsection{Project Management - J. Wood}

Task Description - Coordinate all aspects of the project between Michigan Technological University (MTU) at Houghton, Michigan, Western Michigan University in Kalamazoo, MI and Cronus Exploration Company LLC in Traverse City, MI. Produce a working document that will outline the project in detail as well as set a schedule of visits and meetings. Coordinate all necessary meetings and will serve as the central repository for all project deliverables and reports.

\subsubsection{Technical Aspects - J. Wood}

\section{Policy - Preparation and Enforcement}

The principal subtasks performed were the preparation of this document, including the master outline and coordinating a geochemical sampling party. Separate subcontracts were negotiated and submitted to Western Michigan University and Cronus Exploration Company LLC by Michigan Technological University. An arrangement has been worked out with Western Michigan to permit the Core Lab at WMU to submit invoices to Michigan Tech. This will facilitate payment for services delivered. Two new subcontracts have been submitted to Jordan Energy for work on two new demonstration wells in Michigan.

\section{Travel, Students and Expenditures}

To date 15 sampling trips have been made to downstate Michigan to Vernon Field and to N. Dakota. Several trips have also been made to potential project sites. Expenses were paid for Wood and Bornhorst to present papers on the project at the Eastern AAPG meeting this past September.

The project presently supports 2 Masters students, Mr. Chris Seaman. Me M. Le has joined the group this past summer and will work on a project involving reconstructing depositional environments of the Dundee Formation.

\subsubsection{Financial Reports and Accounting - A. Hein}

\section{Financial documents}

All monthly, quarterly and annual statements and documents have been submitted, including the project Management Plan

C. Asiala has organized a system for keeping copies of all expenditures, bills, invoices and related financial documents that concern this project. The university is keeping track of personnel time and pay for all parties. So far only Michigan Tech is drawing personnel salaries from this project.

\subsubsection{Archives - C. Asiala}

\section{Archival of Materials and reports}

Electronic copies of geochemical data have been received from vendors and archived in project databases. These databases have been backed up. Printed versions will be included in reports, including this one. 
The Atlas program has been altered to plot the GeoChem Sample locations in bubble plots according to the type of chemical concentration chosen by the user. The GeoChem data can be plotted simultaneously with the well locations or it can be plotted separately. The GeoChem data can also be edited from within the Atlas program. The GeoChem data is stored in 2 tables separate from the well data tables. The first table holds the Permit (unique number assigned to the sample) and its latitude/longitude coordinates. The second table holds the Permit, type of concentration, and concentration value. This allows multiple GeoChem concentration values for each sample.

The Subsurface Visualization Lab Web Site (http://www.geo.mtu.edu/svl) has been updated with reports and figures that pertain to the project. Ongoing updates will be added throughout the project.

\section{Processing of DEM and SDTS files}

In addition to the work in the first Budget Period on Digital Elevation models (DEMs), work has expanded this Budget Period to include gravity data from NOAA on the Central Michigan Basin. This data will be integrated with the rest of the project data and used to help interpret the structural model for the Michigan Basin. We recently obtained high resolution $(30 \mathrm{~m})$ DEMs for the State of Michigan without the errors (striping) that plagued the earlier versions.

\subsection{Reservoir Characterization - W. Harrison}

Task Description - Collect, analyze and integrate geologic and engineering data on the Vernon reservoir, particularly structural and stratigraphic data and engineering properties. Determine the reservoir architecture as well as possible prior to drilling the test well. Acquire and interpret 2D seismic line(s). Design, execute and interpret surface geochemical survey(s). Make economic projections and help site wells for development.

\subsubsection{Surface Geochemistry - T. Bornhorst}

Work on this task will continue in Budget Period II. To date over 1500 samples have been collected from 1090 locations. A number of cores (5) have been examined for diagenetic fabrics and fractures, most from the Dundee Formation. A photographic atlas is being compiled for the central Michigan Basin.

\subsubsection{Reservoir Geology - S. Chittick}

\section{Subsurface data}

We have continued to update and edit subsurface data in our master database files. Presently most of our efforts are going into correcting bad entries and removing duplicate records.

\subsubsection{Engineering Parameters- W. Harrison}

No activity this period. Work will take up when drilling targets have been selected for the Phase II demonstration wells. 


\subsubsection{D Seismic- W. Quinlan}

Earlier it was reported that acquisition of new seismic data had been deleted from the project task list and that we would acquire and process existing data. However we have recently acquired a 3D seismic data set for the N. Dakota study and will begin processing and visualization of that data this next quarter at MTU.

\subsection{Analysis of Producibility Problem(s) - W. Quinlan}

\subsubsection{Drilling - E. Taylor}

Permits were issued for two wells; drilling is scheduled for 4th quarter 2002 and 1st quarter 2003.

\subsubsection{Well Logging - S. Chittick}

A number of well logs have been digitized for this study, bringing the total number available to over 100 . New techniques have been developed to use the gamma ray log to map the Dundee Formation over most of the lower peninsula.

\subsection{Technology Transfer - W. Harrison}

Task Description - Transfer of the technology is recognized as a crucial element in this project. Special efforts will be made to deliver the results in a usable form to our target audience through:

Meetings and personal contacts.

Workshops and training courses on use of the data and software

Electronic distribution of results and data on Internet

Establishing computer links between Michigan Tech and selected companies

As a result of presentations made on the project results at the Eastern AAPG meeting in Kalamazoo last September, several individuals have expressed interest in ATLAS and we are in the process of transferring the program to them.

\subsubsection{PTTC Workshops - W. Harrison}

\section{Workshops}

A workshop is planned for a future date.

\section{Case histories}

Material for case histories is being collected and assembled by Dr. A. Wylie, a new addition to the project staff. The first case history on Vernon Field is presented in this quarterly report. Dr. Wylie will have primary responsibility for developing the well demonstration modules. 


\section{Tutorials}

S. Chittick has developed a tutorial for accessing and displaying high resolution DEM files on the PC.

\subsubsection{Reports - J. Wood}

\section{Publications}

Publish project results in DOE reports and in scholarly journals.

\section{Presentations}

Wood, J. R., 2002 - October EAAPG in Champaign, IL. Presentation of DEM results.

Wood, J. R., 2001 - September EAAPG in Kalamazoo, MI. Presentation of project to date, including last demonstration well and surface geochemistry results.

Wood, J. R., 2001 - September EAAPG in Kalamazoo, MI. Presentation ATLAS software.

Bornhorst, T. J., 2001 - September EAAPG in Kalamazoo, MI. Presentation of project to date, including surface geochemistry results.

Barnes, D., 2001 - September EAAPG in Kalamazoo, MI. Presentation of structural data and interpretation for Vernon Field.

Wood, J. R., 2000 - June SPE Meeting in Long Beach, CA. Presentation of project to date, including surface geochemistry results

Harrison, W. B., 2000 - June DOE Contractors Meeting in Long Beach, CA. Presentation of project to date, including surface geochemistry results

Present results at local and national meeting of geological societies, such as the AAPG.

\subsubsection{WEB Site}

Publish project results, updates and news in hardcopy and electronic newsletters published by The Subsurface Visualization Lab at Michigan Tech. Place relevant results on Internet in timely fashion. 